\title{
TÜRKIYE'DE 1950-1965 DÖNEMINDE TARIM KESiMINDE IŞGÜCÜ VE ÜCRETLi EMEĞE ILIŞKiN GELIŞMELER
}

\author{
Doç. Dr. Ahmet Makal \\ Ankara Üniversitesi \\ Siyasal Bilgiler Fakültesi
}

\section{Özet}

Ikinci Dünya Savaşı sonrası dönemde Türkiye'de her alanda önemli dönüşümler yaşanmıştır. Bu dönüşüm sürecinde istihdamın sektörel dağلlımu da değişmiş; tarım kesiminin payı azalırken, sanayi ve hizmetlerin payı artmıştır. Evrensel deneyimlere koşut biçimde, Türkiye'de de tarım kesimi, gelişen sanayinin hammadde ihtiyacını karşılama ve ona pazar teşkil etme yanında, en önemli işgücü kaynağını da oluşturmuştur. Küçük toprak mülkiyetine dayalı Türk tarımında, dönem içerisinde arazi mülkiyeti itibariyle ciddi bir farklılaşma olmamakla birlikte; teknolojik gelişme, arazi ve işgücü kullanımunı değişime uğratmuştır. Bunun sonuçlarından biri tanmsal işgücü fazlasının artması ve daha çok kişinin ücretli çalışmaya yönelmek zorunda kalması olmuştur. Sayılan bir milyon dolaylarında olan bu ücretliler, kırsal kesimde tarım ve tarım dışı faaliyetlerde çalışmanun yanı sıra; kentsel kesimdeki sanayi kuruluşları ile inşaat vb. işlere de yönelmişlerdir. Başlangıçta geçici, mevsimlik çalışmanın yoğun olduğu bu süreç, zamanla büyük ölçekli iç göçlere yol açarak, tarımsal işgücünün kentlere akmasına yol açmıştır. Çalışmamızda, Türkiye'de dönem içerisinde işgücü ve ücretli emeğe ilişkin olarak yaşanan bütün bu gelişmeler, tarm perspektifinden ele alınmakta; konuya ilişkin istatistiksel veri kaynaklan da eleştirel bir değerlendirmeye tabi tutulmaktadir.

\section{Labour Force and Waged Labour in the Agricultural Sector in Turkey: $1950-1965$}

\section{Abstract}

There had been considerable transformation in Turkey's socio-economic structure during the post-war period. In this transformation period, the sectoral composition of employment changed gradually, reducing its share in agriculture and soaring industrial and service proportion. Sharing the same fate of those in many countries, the agricultural sector in Turkey has not only met the raw material requirements of developing manufacturing industry and become a market for it, but also functioned as a main labour resource. Although the Turkish agricultural sector did not lose its main feature, which has always been characterized with small land ownership, technological developments and other factors changed the land and labour usage. One of the results of this phenomenon is the emergence of a surplus labour in agricultural activities, leading to accompanied migration from rural areas to the cities. In this study, these developments are being examined from a critical perspective. 


\section{Türkiye'de 1950-1965 Döneminde Tarım Kesiminde İşgücü ve Ücretli Emeğe İlişkin Gelişmeler}

\section{GiRiş}

Batı ülkelerinin endüstrileşme deneyimleri, kursal kesimle ilgileri kesilerek kentsel kesimde gelişmekte olan sanayi ve hizmetlerde çalışan ve zaman içerisinde süreklilik kazanan bir işçi sınıfının varlı̆̆ı üzerine kurulmuştu. Türkiye'de Cumhuriyetin başlangıç dönemlerinde yeni gelişmekte olan sanayi kesiminin işgücü ihtiyacını karşılaması gereken Türk tarımı; toprak mülkiyeti ve kullanımı, işletme büyüklükleri ve teknoloji açlarından benzeri bir gelişmeyi olanaksız kılıyordu. Küçük üreticiliğe dayalı bu tarımsal yapı içerisinde, geniş bir ücretliler kitlesi ortaya çıkmadığı gibi, kentsel kesime yönelecek bir işgücü de oluşamamaktaydı. Kendi küçük arazileri üzerinde çiftçilik yapan kişiler, bu arazinin sağladığı olanaklar yetersiz olduğundan, tarım mevsimi dışında bir süre tarımda ya da tarım dışı kesimlerde geçici işçi olarak çalıştıktan sonra, para biriktirip köylerine dönmeyi tercih etmekteydiler. Bu koşullar altında, Cumhuriyetin başlangıç dönemlerinde, süreklilik kazanmamış ve belki de "köylü - işç" kavramıyla ifade edebileceğimiz bir çalışan kategorisi bulunmaktaydı. Bunun sonucu, gelişmekte olan sanayi ve hizmetler kesiminin ihtiyaç duyduğu işgücünü sağlayamaması oldu. Türkiye'nin 1920'lerde başlayan sanayileşme çabalarınun önündeki en önemli engellerden biri, sermaye yetersizliği yanında, gelişmekte olan sanayinin ihtiyaç duyduğu nitelikli işgücünün teminiydi. Işücünün yeterince temin edilememesi, sanayileşme açısından ciddi sinurlamalar ve sorunlar yaratmış; böyle bir işgücünün oluşturulması da, temel iktisadi amaçlardan biri haline gelmişti. Türkiye'de Cumhuriyetin ilk dönemlerinde sürekli bir sanayi işçiliğinin oluşmadığının en önemli göstergelerinden biri, işgücü devir oranlarınun yüksekliğiydi. Bunun sonucunda, iktisadi kuruluşlar rantabl bir biçimde çalışabilmeleri için gerekli işgücünü sağlayamadıklarından, düşük kapasite ile çalışmak zorunda kaldılar ve üretim düzeyinde potansiyel ya da reel düşmeler oldu. Çalışma ilişkileri alanından bakıldığı zaman, süreç nicelik yanunda nitelik yönüyle de değerlendirilmelidir. Kursal kesimden kentsel kesime gelen kişiler, geçici olma yanında, modern çalışma yaşamının gerekli kıldığı nitelik ve eğitime de sahip değildiler. 
Işgücünün niteliksizliği ise başka sorunlar yanunda, işgücü verimliliğinin ve buna bağlı olarak ücret düzeylerinin düşüklüğüne yol açmaktaydı. Sorunun bir başka boyutu ise toplumsal ve sınufsal davranı̧ kalıplarnyla ilgiliydi. Türkiye'de birinci kuşak, üstelik de süreklilik taşımayan ve kırsal kesim kökenli bir işçi kesiminin varlığı, sınuf bilincinin oluşumunu olumsuz yönde etkilemekteydi. Ancak, zaman içerisinde geçmiş dönemin geçici, mevsimlik iş̧̧iliğine dayanan "köylü - işç" tipinin, yerini sürekliliğe dayanan yeni "iş̧̧i" tipine bırakmaya başladığı, işgücünün de giderek nitelik kazandığı görülmektedir. Bu oluşum, uzun bir süreçte ve tedrici olarak gerçekleşmiş, 1950 sonrası dönemde ise ciddi bir devinim kazanmıştır. ${ }^{1}$

Bu devinim, ancak Türkiye'nin Ikinci Dünya Savaşı sonrası yıllarda geçirdiği değişim çerçevesinde anlamlandırılabilir. Bu yıllarda, Türkiye'de siyasal, toplumsal ve iktisadi alanlarda önemli değişimler yaşanmaktaydı. Bu değişim süreci değişik boyutları itibariyle bir bütün oluşturur ve dönüşüm sözcüğüyle nitelenebilecek düzeydedir. Süreç, siyasal alanda, Cumhuriyetin başlangıcından beri sürmekte olan tek partili dönemin son bulması ile karakterize olmaktadır. İktisadi alanda ise daha önceki yıllarda izlenen kapalı ve korumaa iktisat politikaların yerini; 1946'dan başlayarak, ithalatun serbestleştirildiği, dış yardım, dış kredi ve yabancı sermaye hareketlerinin yoğunlaştığı yeni bir dönem aldı. Serbest dış ticaret politikalanı, dış piyasaya yönelik tarım ve madencilik gibi faaliyet alanlanyla, inşaat ve altyapı yatırımlarına ağırlık verilmesi sonucunu doğuracaktı. Çalışma ilişkileri alanında da bunlara koşut radikal değişimler yaşandı. 1946 yılında Cemiyetler Kanunu'nun değiştirilmesiyle, tek parti döneminde var olan fiili ve hukuki sendika kurma yasağı ortadan kalktı ve sendikaların kurulması mümkün hale geldi. Daha sonra 1947 yılında çkarılan 5018 sayılı Iş̧̧ ve İşveren Sendikaları ve Sendika Birlikleri Hakkında Kanun'la Türkiye çalışma ilişkilerinde yeni bir dönem başladı.

Bu dönemde iktisadi alanda yaşanan gelişmeler, istihdam açısından da önemli sonuçlar yarattı. Istihdamın sektörel dağılımı değişime uğradı; tarım kesiminin payı azalırken, diğer kesimlerin payı artt. Tarım kesiminin toplam istihdam içerisinde 1950 'de \% 84.8 olan payı, 1960 yılında \% 74.8'e düşmüştü. Aynı dönem içerisinde sanayinin payı \% 8.4'ten \% 11.5'e; hizmetlerin payı ise \% 5.2'den \% 13.7'ye yükseldi (BULUTAY, 1995: 189, Tablo 7.1). Işgücü, bu değişim sürecinde sektörel dağılım dışında; mesleki ve coğrafi dağılımı ile nicelik ve nitelik itibariyle de dönüşüme uğradı. Bir başka önemli değişiklik işgücünün statüsü itibariyle ortaya çıkt ve işgücü içerisinde ücretlilerin oranı ciddi

1 Bưrada genel çizgileriyle değerlendirilen gelişim, daha önceki bir çalışmamzda kapsamlı olarak ele alınmıştı. Bakınz, (MAKAL, 1999: 295-303). 
ölçülerde arttı. ${ }^{2}$ Ücretliler, giderek nitelik ve süreklilik kazandılar. Kuşkusuz bütün bu gelişmeler içerisinde sanayi ve hizmetler kesimi belirleyici hale geldi ve değişimler büyük ölçüde bu sektörler itibariyle ortaya çıktı. Bu durum, Türk sosyal politika yazınında döneme ilişkin araştırma ve değerlendirmelerin de ağırlıklı olarak bu sektörler üzerinde odaklanmasına yol açtı. Bunun sonuçlarından biri, işgücü ve ücretli emek açısından tarım kesiminin ve buradaki çalışma ilişkilerinin ihmal edilmesi oldu. Oysa, kanumızca, tarım kesimi zannedilenin aksine, birçok açıdan hayati bir öneme sahipti. Birinci olarak, tarım kesimindeki işgücü nicelik ve nitelik açısından önemli değişimler geçirmekte ve ücretli emek önemli bir yere sahip bulunmaktayd. Yani, salt tarım kesimi açsından bile, buradaki ücretli emek olgusu önemliydi. Ikinci olarak, tarım ile diğer kesimlerdeki değişimler arasında bir kopukluk değil; diyalektik bir bütünlük vardı. Tarım kesimi, kendi işgücü ihtiyacının yanı sıra, zanaatlarla birlikte; gelişmekte olan kentsel kesimdeki sanayi ve hizmetlerin ihtiyacını da karşılayacak en önemli insan gücü kaynağı olma durumundaydı.

Genel çizgileriyle değerlendirdiğimiz tüm bu gelişmeler, Türkiye'de tarım kesiminde işgücü ve ücretli emek itibariyle ortaya çıkan oluşumların; tarımın kendisi kadar, tarım dışı kesimler açısından da hayati öneme sahip olduğunu göstermektedir. Çalı̧̧mamızda, dönem içerisinde işgücü ve ücretli emek açısından meydana gelen gelişmeler, tarım kesimi merkez alınarak incelenmektedir. Bu çerçevede tarım kesiminde işgücünde meydana gelen gelişmeler, tüm statüler yanında özellikle ücretli emek açısından ele alınmakta; çeşitli eksikliklerle ve metodolojik hatalarla malul olan istatistiksel veri kaynakları da eleştirel bir değerlendirmeye tabi tutulmaktadır.

Bir tarih çalışmasında incelenen dönemi, öncesi ve sonrası ile bağlantılı olarak değerlendirmek zorunludur. Bu nedenle, çalışmamızın ekseninde 1950-1960 döneminde yaşanan gelişmeler yer almakla birlikte, inceleme dönemi 1950-1965 olarak belirlenmiştir. Bu tercihimizde, 1963 Tarım Sayımı ve 1965 Genel Nüfus Sayımı gibi istatistiksel veri kaynaklarını değerlendirebilmek kaygısı da önemli rol oynamıştır. Gene aynı kaygıyla, mümkün olan durumlarda 1950 öncesi döneme uzanmaktan da kaçınılmamıştır. Buna karşılık, istatistiksel kaynaklardaki metodoloji farklılıklarından dolayı, her durumda bu yılların tümüne ilişkin verileri kullanmak mümkün ve anlamlı olmamaktadır.

2 Işgücünün statüsü ile eşanlamlı olarak "isgücünün meslekteki mevkii", "işgücünün çalışma durumu" gibi kavramlar da kullanılmakla birlikte, biz "statü" kavramın tercih ediyoruz. 


\section{ETKILERi \\ II. TARIM KESIMINDEKi YAPISAL DEĞişiMLER VE işGūcō ŪZERINE}

\section{A. Arazi Mülkiyetindeki Değişmeler}

Kuramsal olarak, tarım kesiminde ortaya çıan değişimlerin altında yatan önemli faktörlerden biri toprak mülkiyetidir. Bu nedenle, dönem içerisinde Türk tarımı, öncelikle arazi mülkiyetindeki gelişmeler ve bunun olası etkileri itibariyle değerlendirilmelidir. Soruna kırsal kesimde arazi mülkiyetindeki değişmelerin tümü bağlamında ve toprak temerküzü açısından yaklaşıldığında en azından istatistikler düzèyinde, arazi mülkiyetinde ciddi değişimlerin ortaya çımadığı görülmektedir. Bu konuya ilişkin bilgiler, 1950 ve 1963 Tarım Sayımları ile 1952 Sonbahar Anketi'nden elde edilebilmektedir. 1950 ve 1963 Tarım Sayımı sonuçları karşılaştırıldığında, 50 dönümden küçük cüce işletmelerin oranında ve işledikleri toprak oranında artma olduğu görülmektedir. Buna karşılık, bu gruptaki işletmelerin ortalama arazi büyüklüğü düşmektedir. 500 dönümden büyük işletmelerin oranları ile işledikleri toprak miktarının da düştüğü görülmektedir. 50-500 dönüm arasındaki küçük ve orta işletmelerin toplam içerisindeki oranları ise \% 36.7'den $\%$ 30.7'ye düşerken; işledikleri arazinin payı \% 54.8'den \% 64.6'ya yükselmektedir. Sonuçlar, küçük ve cüce işletmelerin ağırlığının, daha çok orta ve orta altı işletmelerin parçalanmasıyla arttığını göstermektedir (VARLIER, 1978: 12). Bütün bu veriler dahilinde yapılan hesaplamalar, tarımda temerküz oranlarının yükselmek bir tarafa, 0.37 'den 0.32 ye düştüğünü göstermektedir (DlE, 1973: 109).

Arazi mülkiyeti itibariyle yapılan bu çözümlemenin tamamlanması için, hiç bir mülkiyet kategorisine girmeyen topraksız köylülerin durumlarının değerlendirmeye katılması gerekir. 1950 Tarım Sayımı sonuçlarına göre toplam 2760304 aileden $336860^{\prime}$, yani \% 12.20'si tümüyle topraksızdır (KANBOLAT, 1963: 33). 1963 Sayımi'na göre ise toplam 3514476 aileden 308899 'u, yani \% 8.79'u topraksızdır (DIE, 1965a: 6). Bu kategorideki aile fertleri, yaşamların sürdürebilmek için geçici ya da sürekli tarım iş̧̧iliğine yönelecekler ya da ortakçılık - kiracılık yoluyla geçimlerini sağlamaya çalışacaklardır. Türk tarımında dönem içerisinde gözlenen ve aşağıda kapsamlı bir biçimde ele alınacak gelişmeler; ortakçlık - kiracılık ilişkilerinin zayıflamasına yol açarak, topraksız köylüleri sürekli ücretli iş̧̧iliğe itecektir. Ancak, tarım kesiminde makinalaşmayla birlikte özellikle sürekli iş̧̧ilik olanakları da daraldığı için, bu kişiler daha çok kentsel bölgelere yöneleceklerdir. Kuşkusuz benzeri çözümlemeler, topraksız köylüler yanında, daha düşük ölçülerde olmakla birlikte; cüce ve küçük işletmelerin sahipleri açısından da yapılmalidır.

Aşağıdaki tabloda 1950 ve 1963 Tarım Sayımları ile 1952 Anketi sonuçlarına göre, arazi mülkiyetine ilişkin veriler görülmektedir. 
Tablo I: Tanmsal Işletmelerin Dağılumundaki Değişmeler (1950, 1952. 1963)

\begin{tabular}{|l|l|l|l|l|l|l|}
\hline $\begin{array}{l}\text { Toprak } \\
\text { dilimleri }\end{array}$ & \multicolumn{2}{|l|}{1950 Tarım Sayımı } & \multicolumn{2}{l|}{1952 Sonbahar Anketi } & \multicolumn{2}{l|}{1963 Tarım Sayımı } \\
\hline & $\begin{array}{l}\text { Işletme } \\
\text { yüzdesi }\end{array}$ & $\begin{array}{l}\text { Toprak } \\
\text { yüzdesi }\end{array}$ & $\begin{array}{l}\text { Işletme } \\
\text { yüzdesi }\end{array}$ & $\begin{array}{l}\text { Toprak } \\
\text { yüzdesi }\end{array}$ & $\begin{array}{l}\text { Işletme } \\
\text { yüzdesi }\end{array}$ & $\begin{array}{c}\text { Toprak } \\
\text { yüzdesi }\end{array}$ \\
\hline $1-20$ & & & 30.57 & 4.30 & 40.92 & 7.03 \\
\hline & 61.84 & 18.91 & 62.12 & 18.64 & 68.77 & 24.38 \\
\hline $21-50$ & & & 31.55 & 14.34 & 27.85 & 17.35 \\
\hline $51-100$ & 21.89 & 18.77 & 21.84 & 20.62 & 18.12 & 23.87 \\
\hline $101-200$ & 10.51 & 19.08 & 10.28 & 19.31 & 9.41 & 23.74 \\
\hline $201-500$ & 4.17 & 16.87 & 4.25 & 16.61 & 3.22 & 16.98 \\
\hline $501+$ & 1.59 & 26.37 & 1.52 & 24.81 & 0.50 & 11.02 \\
\hline Toplam & 2512800 & $20750591 \mathrm{Ha}$ & 2527800 & $19451940 \mathrm{Ha}$ & 3100850 & $16734335 \mathrm{Ha}$. \\
\hline
\end{tabular}

Kaynak: BIUM (1956:122), DIE (1965a: 6-7), KETEN (1971: 76), VARLIER (1978: 23, Tablo:1-11)'den düzenlenmiş ve hesaplanmıştur.

Ancak, bu verileri, özellikle 1963 yllına ilişkin olarak yorumlarken ihtiyatlı davranmak gerekir. 1960 sonrası dönemde yoğun biçimde tartışılan toprak reformu konusu, özellikle büyük toprak sahiplerinin eksik bildirimine yol açtığı için, 1950-1963 yılları arasındaki değişimleri, bu veriler aracılığıyla net bir biçimde izlemek zor gibi görünmektedir. ${ }^{3}$ Bu aksaklığı da hesaba katan daha ihtiyatlı yorumlar, her şeye karşın Türkiye'de tarımda bir yoğunlaşma ve toprak temerküzü olduğu, bu topraksızlaşma sürecinin üst ucunda tarımsal işletme ölçeğindeki büyüme ve sermaye birikiminin gözlendiği ve bu sürecin tarımda makinalaşmayı izleyen işletme ölçeği büyümesi, atıl toprakların ekilişe açılması veya küçük köylüden toprak satın alınması ya da kiralanmasıyla birlikte geliştiği doğrultusundadır. ${ }^{4}$

Ancak, tarım kesimi açısından arazi mülkiyetindeki değişimler son derecede önemli olmakla birlikte; bunun insan gücü ve işçleşme süreci

3 Bu konuda, bakınz, (DIE, 1973: 109; KEPENEK, 1987: 95).

4 Bakınız, (KAZGAN, 1983: 131). Varlıer de, 1950-1973 dönemini karşılaştırdığı çalışmasında, bir taraftan Türkiye tarımında küçük ve cüce işletmelerin ağırlığı artarken, diğer taraftan daha büyük toprakların giderek daha az sayıda işletmenin elinde toplanması olarak nitelenebilecek toprak yoğunlaşmasının çok hızlı olmayan bir biçimde süregeldiğini belirtmektedir. Bakınız, (VARLIER, 1978: 14-15). 
itibariyle etkilerini, sadece bu düzeyde ele almamak icap eder. Tarım kesimindeki değişimleri ve bunun sanayileşme ile işçileşme süreci üzerindeki etkilerini sadece mülkiyet ilişkileri ve dolayısıyla mülksüzleşme kavramı çerçevesinde ele almak, sık yapılan bir hatadır. Bu yaklaşıma göre, iş̧̧leşme süreci mülksüzleşme sürecinin bir sonucudur ve toprak üzerindeki küçük arazi mülkiyeti bunu olanaksız kılmaktadır. Bu yaklaşım konusunda ilk söylenmesi gereken, küçük arazi mülkiyetinin iş̧ileşme olgusunu mutlak anlamda dışlamadığıdır. Aile işletmesi mutlaka ücretli iş̧̧iyi dışlayan bir olgu olmayıp, küçük meta üreticisi aile işletmeleri bazan kendileri ücretli işçi olup, bazan de ücretli geçici iş̧̧i kullanabilmektedirler (KAZGAN, 1988b: 176). Boratav'ın ifadesiyle, "Köylü işletmesi küçük üretici niteliğini korumasına rağmen, demografik devresinin belli aşamalarında emek fazlası içererek işgücü "ihraç" edebilir, diğer aşamalarında ise emek kıtlığı durumuna düşerek yabancı işgücü kullanabilir. Keza, yllık üretim devresinin, hasat dönemi gibi belli anlarında köylü işletmesi, yerel olarak varolan, veya bölge dışından gelen emek fazlasına ve tarım iş̧̧ileri kitlesine başvurarak ücretli işgücü istihdam edebilir. Bu durumlarda başvurulan emek fazlaları, tamamen topraksız bir tarım proleteryasından ve köylü işletmesindeki emek fazlasının işgücü piyasasına taşmı̧̧ unsurlarından oluşabilir." (BORATAV, 1980: 25). Türkiye düzleminde, tarım işçiliğini sadece topraksız köylü aileleriyle özdeşleştirmek, küçük arazi sahibi aile fertleriyle tarım işçiliği arasındaki ilişkiyi göz ardı etmek, son derecede yanultıcı olacaktır. Bu noktada, kanımızca üç ayrım yapmak ve çözümlemeleri bu ayrımlar çerçevesinde sürdürmek icap eder. Bunlardan birincisi, sürekli ve geçici iş̧̧i ayrımıdır, ikincisi tarım kesiminde çalışan ve tarım dışı kesimlerde çalışan iş̧̧iler arasındaki ayrımdır, üçüncüsü ise kursal kesimde tarımsal faaliyetlerle tarım dısı faaliyetlerde çalışma arasındaki ayrımdır. Ayrıca, başta makinalaşma olmak üzere; tarım kesiminde işgücü ve iş̧̧leşme sürecini etkileyen çok sayıda faktör bulunmaktadır ve arazi mülkiyeti bunlardan sadece biridir.

Tarım kesiminde toprak mülkiyeti yanunda toprağın tasarruf biçimi de işgücü ve iş̧̧ileşme üzerinde etkindir. Çünkü toprak, sahip olmanın dışında; kiracılık, ortakçılık vb. yollarla da kullanılabilmektedir ve bu da işgücü kullanım sürecini ve iş̧̧ileşmeyi etkileyici sonuçlar doğurmaktadır. Toprağın tasarruf biçimlerine ilişkin olarak 1950 ve 1963 sayımları farklı yöntemler kullandığ i için, sağlıklı bir karşılaştırma mümkün olmamaktadır. 1950 Sayımında mal sahipliği ile farklı arazi kullanım biçimleri; işlenen toprakların büyüklüğü değil, sadece aile sayısı itibariyle değerlendirilmişti. Buna göre, toplam 2274000 aileden mal sahibi olanların sayısı 1686000 yani \% 72.6, yarı mal sahibi olanların sayıs1 499 000 yani \% 21.5 idi. Geriye kalan \% 5.9'luk bölüm ise kiracı - yarıcı - marabacı şeklinde tasnif edilmişti (BÍUM, 1956: 122). Ancak buradaki yarı mal sahiplerinin gerçekte çok küçük bir toprağa malik olduklan ve bu nedenle kiracı - ortakçı grubuna katılmalarınn gerekli olduğu düşünülebilir (KANBOLAT, 
1963: 34; AKTAN, 1978: 187). Bu durumda 1950'de Türkiye tarımunda ailelerin yaklaşık \% 22'sinin kiracalık - ortakçllk kategorisi içerisinde yer aldığ söylenebilir ki, bu yüksek bir orandur. Buna topraksız köylülerin ilave edilmesi durumunda; çok daha büyük bir orana ulaşlacaktır. 1963 Tarım Sayımı sonuçları ise işletme sayısı itibariyle yapılan değerlendirmeler yanında, işlenen arazinin miktarın da vermektedir. Buna göre toplam 4000318 işletmeden 3069 921'inin mal sahipliği yoluyla işlendiği görülmektedir. Diğer işletmeler ise kiracılık - ortakçlık - yarıcılık ve başka biçimlerde işlenmektedir (DIE, 1965a: 1). Birinci kategorideki işletmelerin oran \% 74.61 iken, işlenen toprak oran \% 86 dolaylarındadır. Ancak rakamların karşlaştırmaya uygun olmadığı tekrar ifade edilmelidir. ${ }^{5}$

\section{B. Tarımda Teknolojik Değişme, Makinalaşma ve Etkileri}

\section{Tanmda Makinalaşma}

Dönem içerisinde arazi mülkiyetinde ciddi değişmeler olmadığı halde tarım kesiminin tümü itibariyle önemli değişimler ortaya çımaktadır. O halde, bu değişimlerin nedenlerini büyük ölçüde arazi mülkiyeti dışındaki faktörler itibariyle değerlendirmek icap etmektedir. Bu faktörlerin başında ise teknolojik değişmeler gelmektedir. Burada teknolojik değişme kavramı, mekanik ve biyolojik değişmeleri içermek üzere kullanılmaktadır. Mekanik değişmeler, tarımda makinalaşmayı; biyolojik değişmeler ise büyük ölçüde vasıflı tohum, kimyasal gübre ve zirai mücadele araçlarını içermektedir. ${ }^{6}$ Türkiye'de Cumhuriyet'in kuruluşundan itibaren tarım kesiminde teknolojik gelişmenin sağlanmasina yönelik çabalar gösterilmiş, ancak 1950 öncesi dönemde bu çabalar, değişik nedenlerle başarılı olamamıştır. ${ }^{7} 1950$ 'li yıllar ise Türk tarımında, 1970'li yıllarla birlikte, teknolojik değişmenin yoğunlaştığı iki dönemden biridir (KAZGAN, 1988a: 263). Dönem içerisinde Türk tarımında hem mekanik, hem de biyolojik alanda değişmeler olmuştur. Mekanik değişmelerin başında kullanılan traktör sayısında gözlenen artışlar gelmektedir. 1948 yılında sadece 1756 olan traktör say1s1, 1955'te 40 282'ye, 1960'ta 42 136'ya, 1965 'te ise 54 668'e çıkmıştır (TARIM BAKANLIĞI, 1968: 27, Tablo 12). Traktör sayısı, 1948-1960 döneminde 23.99 kat, 1948-1965 döneminde ise 31.13 kat artmıştır. Ancak, bu artı̧̧a karşın, dönem içerisinde traktörle işlenen alanların oranı gene de sınurlı kalmıştır. Bunda, traktör artışıyla birlikte, ekilen toprakların da geniş ölçüde artması etken olmuştur. Traktörle işlenen toprakların oranı

5 Cillov, toprağın tasarrufu itibariyle iki sayımın sonuçlarının çok da farkh olmadığı düşüncesindedir. Bakınız, (CILLOV, 1972: 180).

6 Burada kullanilan ayrim ve kavramlar konusunda, bakıniz, (ARUOBA, 1988: 199).

7 1923-1948 döneminde tarımda teknolojik gelişmeyi sağlamaya yönelik politika ve uygulamalar konusunda bilgi, (TEKELI / ILKIN, 1988)'de bulunabilir. 
1951 'de \% 11.79, $1955^{\prime}$ te \% $14.39,1960$ 'ta \% 13.58 ve $1965^{\prime}$ te \% 17.40 'tur (DIE, 1973: 111). ${ }^{8}$ Dönem içerisinde diğer tarım makinalarında da artışlar olmuş; 1948-1965 arasinda biçer-döver sayısı 24.40 , tınaz makinası sayısı 4.79 , motopomp sayısı ise 198 kat artmışır. ${ }^{9}$ Biyolojik değişme çerçevesinde ise bazı tarımsal girdilerin kullanımında artş̧ar olmuştur. Kullanılan kimyevî gübre miktari 1948-1965 döneminde 58.81 kat artmıştır. ${ }^{10}$ Kullanulan ziraî mücadele ilaçlan ise 1952-1965 döneminde yaklaşık 13.79 kat artmıştır. ${ }^{11}$ Tüm bu gelişmeler, başka faktörlerle birleşerek Türk tarımında ciddi değişimler doğurmuştur.

\section{Makinalaşmanın Etkileri}

\section{a. Ekilen Topraklarda Genişleme}

Kuramsal olarak, toprak kullanımıyla tarımda kullanılan üretim teknikleri arasında yakın bir bağlantı mevcuttur. Geri teknoloji, değişik nedenlerle işlenen toprak miktarın olumsuz yönde etkilemektedir. ${ }^{12}$ Bu bağlantı, Türkiye'de tarımda ileri tekniklerin yeterince kullanılmadığı dönemlerde açık bir biçimde gözlenebilmektedir. ${ }^{13} 1950$ sonrası dönemde ise makinalaşmanun ilk etkilerinden biri, ekilen topraklardaki genişleme olmuştur. Makinalaşma sonucunda toprağın marjinal verimi, yani toprak talebi artmıs, ekilişler genişlemiş; çeki gücü eksikliği dolayısıyla mer'a ve çayır olarak atıl tutulan topraklar ekilişe açlmıştır (KAZGAN, 1983: 126; KAZGAN, 1988a: 264). Istatistiksel verilere göre 1945 yllında 12 664, 1950'de 14542 bin hektar olan işlenen topraklar, 1960 yllında 23264 bin hektara çıkmışı (KEPENEK, 1987: 93, Tablo V.4). Türkiye yüzeyinin yüzdesi olarak ise ekili toprakların oran 1950 yılında \% 18.7 iken, 1960'ta \% 29.9'a yükselmişti (DPT, 1963: 26, Tablo 20). "Işlenen toprakların genişlemesi, büyük ölçüde ya tümüyle kamu mülkiyetinde olan, ya da köy birimlerinin ortak kullanımında bulunan arazinin özel kişilerce işlenmesi biçiminde oldu. Bir başka deyişle, kursal kesim topraklarında özel mülkiyet, büyük toprak sahipleri, daha doğrusu traktör sahibi olabilen çiftçiler yararına genişledi." (KEPENEK, 1987: 93). Ekilen topraklardaki genişlemenin ise işgücü ihtiyacı ve işçileşme süreci üzerinde önemli etkileri olacaktır.

Ancak, dönem içerisinde ekilen topraklardaki genişlemenin temel nedenlerinden birisi makinalaşma olmakla birlikte, diğer nedenleri de göz ardı etmemek gerekir. 1950 öncesi dönemde düşük düzeyde toprak kullanımınn en önemli nedenlerinden birisi, üretim tekniklerinin geriliği ise; diğeri tarımın

8 Oran, 1965'i izleyen 5 yll içerisinde \% 100 artarak, 1970'te \% 32.71'e yükselecektir.

9 (TARIM BAKANLIĞI, 1968: 27, Tablo 12)'den hesaplanmıştır.

10 (TARIM BAKANLIĞI, 1968: 25, Tablo 10)'dan hesaplanmıştır.

11 (TARIM BAKANLIĞI, 1968: 25, Tablo 11)'den hesaplanmıştır.

12 Bu nedenler konusunda, bakınız, (ARUOBA, 1982: 81).

13 Bakını, (ARUOBA, 1982: 81 vd.). 
pazarlara açıma, ulusal ve uluslararası pazarlarla bütünleşme oranının zayıflığıdı. Bunun temel nedenleri ise ulaştırma ve taşımacılık alanlarındaki gerilikti (ARUOBA, 1982: 82). 1950-1960 döneminde bu alanlarda sağlanan gelişmeler de, makinalaşmaya ilave olarak, ekilen toprak miktarındaki artı̧ ve tarımsal üretim üzerinde olumlu etkiler yapt.

\section{b. Makinalaşmanun İsgücü ve İş̧ilik Üzerindeki Etkileri}

Makinalaşma, işlenen toprakları artırırken, işgücü üzerinde de etkili oldu. Kuramsal olarak makinalaşmanun işgücü üzerine etkileri çift yönlüdür. Makinalaşma bir yandan işgücü ihtiyacun azaltırken, diğer yandan artırmaktadır. Birinci yönü itibariyle, mülkiyet yapısı sabitken, makinalaşma toprağın ortakçllı ve kiracılık kategorileri içerisinde kullanımın olumsuz yönde etkilemekte, bu yönüyle bir bölüm işgücünü serbest bırakarak iş̧̧leşme süreci üzerinde etkide bulunmaktadır. Türkiye'de 1950'li yıllarda özellikle orta ve büyük işletmelerde makinalaşmanun artması, ortakçllk ve kiracilık sistemiyle çalışan köylülerin kitle halinde işsiz kalmasına neden oldu (KANBOLAT, 1963: 42). ${ }^{14}$ Ancak, makineleşmenin ortakçlık ve kiraclık üzerindeki etkileri farklı olmuştur. Türkiye'de makinalaşmanun hızlanmaya başladığı 1950'li yılların başında Siyasal Bilgiler Fakültesi tarafından gerçekleştirilen "Türkiye'de Zirâ̂ Makinalaşma" araştırması; kiraçlık artarken, ortakçlığın gerilediğini ortaya koymaktadır. Bu, makinalaşmış çifţ̧ilerin arazileri kiralayarak kendileri işletme eğilimi içerisinde olmalarından kaynaklanmaktadır (SBF, 1954: 110). Ancak durum makinalaşmış çiftçiler dışında değerlendirildiğinde; genel çizgileriyle hem ortakçlik hem de kiracilık kategorilerinde azalma yaşanmaktadır (SBF, 1954: 129). Bu durumda eskiden ortakçılık ya da kiracılık yaparak yaşamını sürdüren bir işgücü kategorisi, makinalaşmanun etkilediği toprak kullanumı sonucunda işsiz kalacak ve tarım kesiminde ya da tarım dışı kesimlerde iş aramaya yönelecektir. Daha sonraki tarihlerde yapılan değerlendirmeler de, makinalaşmanun ortakçlık kategorisi kadar kiracılık kategorisinde çalışanları da olumsuz yönde etkilediğini ortaya koymaktadır. ${ }^{15}$

Bununla birlikte, gene ayn makinalaşma, işgücü ihtiyacını artırıcı yönde etkiler de yapmaktadır. Bu artırıa etkinin iki boyutu vardır. Birinci olarak, makinalaşma, bu makinaların kullanımında, işletilmesinde ve tamirinde çalışan şoför, makinist, tamirci. ustası gibi kategorilerde çalışanların sayılarında artışlara yol açmaktadır. Siyasal Bilgiler Fakültesi araştırması, bu kategorilerde çalışanların küçümsenmeyecek düzeyde olduğunu göstermektedir. ${ }^{16} \mathrm{Bu}$

14 Kanbolat’a göre, aslında "ortakçılık şekli altunda çalışanlar bile gerçekte birer tarmm iş̧̧isinden başka şey değildir." Bakınız, (KANBOLAT, 1963: 65).

15 Bakınız, (KANBOLAT, 1963: passim).

16 Bakını, (SBF, 1954: 50 vd.). 
kategorilerin dışında, makinalaşmayla birlikte özellikle büyük işletmelerde ve endüstri bitkileri alanunda geniş çapta bir tarım işçisi gereksinimi de ortaya çıkmaktadır. Araştırma, 1952 yılında makinalı çiftçilerin \% 88 gibi büyük bir oraninun ücretli iş̧i istihdam etmekte olduğunu ortaya koymuştur (SBF, 1954: 92).

Makinalaşmanun işgücü ihtiyacı üzerindeki bu olumlu ve olumsuz etkileri bir arada değerlendirildiğinde; olumsuz yani işgücü ihtiyacını azaltıcı etkisinin daha ağır bastığı görülmektedir. Teknik gelişmenin tarımda kapattı̆ı iş sahası, açtığ 1 iş sahasından daha fazla olduğu için, makinalaşma, tarımda belirli bir alan için duyulan işgücü miktarın mutlak olarak azaltmaktadır (KANBOLAT, 1963: 58). ${ }^{17}$ Ancak, dönem içerisinde Türkiye'nin durumu değerlendirilirken, ekim yapılan toprakların sabit olmadığı, ciddi artışlar gösterdiği de dikkate alınmalıdır. Türkiye'de 1950'li yullarda ekilen toprak miktarında ciddi artışlar olduğu için, traktörle işlenen arazinin mutlak miktarında ve oranında artı̧ olmakla birlikte, traktörle işlenmeyen toprakların mutlak miktarında da artışlar olmaktadır. Bu gelişmelerin sonucunda, belirli bir alan başına işgücü ihtiyacı azalmakla birlikte; toplam olarak işgücü miktarı artabilecektir. Bu işgücü küçük aile işletmeleri içerisinde, kiracılık - ortakçılık kategorileri içerisinde ya da iş̧̧ilik kategorisi içerisinde yer alabilecektir. Ancak, son kategori içerisindeki artışın sürekli iş̧̧ şeklinden çok, mevsimlik iş̧̧i şeklinde tezahür etmesi söz konusudur. Nitekim "Türkiye'de Ziraî Makinalaşma" araştırması, makinalı çiftçilerin çalıştırdığı geçici iş̧̧ilerin sayısında artış olduğunu, buna karşılık sürekli iş̧̧ sayısında azalma olduğunu ortaya koymuştur (SBF, 1954: 93). Araştırma sonuçları, makinalaşma ile bu eğilimin devam edeceği beklentisini de ortaya koymaktayd.

Türkiye'de 1950'li yllarda bu iki yönlü gelişme sonucunda; hem kentsel kesime işgücü kayışarı olmuş, hem de bunu gerçekleştiremeyen bir nüfus kitlesi kırsal kesimde geçici iş̧̧iliğe yönelmiştir. Bu gelişmeler ise tarım kesiminin kendi içinde değişimler yarattığı kadar, sanayi kesimi açısından da önemli sonuçlar doğuruyordu. Değişmeler; tarım kesiminin insan gücü ihtiyacını azaltarak; topraktan göreli olarak kopmuş, özgürleşmiş bir işgücü tabakası doğurma yanında; yeni gelişen sanayi kesiminin insan gücü ihtiyacını karşılama ve bir ücretliler kitlesinin gelişmesinde etkin olmuştur. Ancak, inceleme dönemimiz içerisinde bu gelişmelerin sınırlı olduğu da belirtilmelidir. Nitekim, sanayi kuruluşlarında iş̧̧i devir oranlarında daha önceki döneme göre düşmeler olmasına karşın, henüz kalıc değişiklikler meydana gelmemektedir. Konuya ilişkin esas gelişmeler ise 1960 sonrası dönemde yaşanacaktır. Ekilen toprakların sınırlarına ulaşıldığı bir durumda zirai makina ve girdi miktarındaki

17 Bir traktörün ortalama 5 ile 9 kişi arasında nüfusu tarımdan serbest bırakacağı (işsiz durumuna düşüreceği)" ifade edilmektedir. Bakınız, (YAVUZ / KELEŞ / GERAY, 1978: 827). 
artı̧̧lar, 1960 sonrası dönemde tarım kesiminde işgücü ihtiyacını 1950-1960 dönemine göre ciddi ölçüde ve net biçimde azaltacaktır.

\section{Tarım Kesimine lliş̧in Diğer Gelişmeler}

Dönem içerisinde tarım kesimine ilişkin gelişmeleri; mülkiyet, makinalaşma, toprağın kiraclık-ortakçılık ilişkileri içerisinde kullanımı ve tüm bunların işgücü ve iş̧̧leşme üzerindeki etkileri dışında; başka faktörler itibariyle de değerlendirmek icap eder. 1950'li yıllarda hükümetin izlediği tarım kesimine yönelik iktisat politikaları sonucunda; tarımsal ürünlere sübvansiyonlar yapıldı, bu kesime yönelik kredi olanakları genişledi. Ziraat Bankasi'nun tarımsal kredileri 1948 yllında 237303000 TL iken, 1950 yllında 1 067665000,1960 yilında 2392097000,1965 yllunda ise 3492240000 TL.'ya ulaştı (TARIM BAKANLIĞI, 1968: 21, Tablo 8). Dönem içerisinde karayolu ulaşımında sağlanan gelişmeler sonucunda tarım kesimi giderek piyasa ekonomisi koşullarına açldd; pazarlanan ürün oran 1950'de \% $33.5 \mathrm{iken}$, bu oran 1960 'ta \% 46.7'ye yükseldi (KAZGAN, 1983: 283). Tüm bu olgular, çalı̧̧mamızda değerlendirdiğimiz diğer ögelerle birlikte, tarım kesimindeki gelişmeler üzerinde etkili oldu. Çalışmamızın ilgi alanı dışında kaldığı için, bu gelişmeleri kapsamlı bir biçimde değerlendirmiyoruz.

\section{TARIM KESIMINDEKI ÜCRETLILER}

\section{A. Tarımsal İ̧̧gïcü Fazlası}

Değerlendirdiğimiz faktörler, Türkiye'de tarım kesiminde kelimenin dar anlamında büyük bir işsizlik ya da kelimenin geniş anlamında büyük bir işgücü fazlasının ortaya çıkması üzerinde etkili olmuşlardır. Tarım kesiminde açık işsizlik, büyük ölçüde, iş bulamayan tümüyle topraksız ailelerle; işgücü fazlası ise bunlarla birlikte, küçük arazi mülkiyetine sahip ailelerle bağlantılıdır. Birinci Beş Yıllık Kalkınma Plânı için yapılan hazırlık çalışmalarında, tarımsal faaliyetlerin doğası itibariyle en yoğun çalışma dönemi olarak kabul edilen temmuz ayında dahi, üretim için gerekli olmayan insan sayısı 1955 yılı için 400 000, 1960 için ise 800000 olarak hesaplanmışt. Diğer aylar için bu işgücü fazlası daha yüksek olup, örneğin en yüksek olduğu ocak ayı için aynı yıllar itibariyle 7 400000 ve 8300 000'dü (DPT, 1963: 445, Tablo 352). Ikinci Beş Ylllk Kalkınma Planı'nda da 1967 yulı rakamları temmuz ayı için 910000 , ocak ayı için 7800000 olarak hesaplanmışt (DPT, 1967: 132, Tablo 63). Temmuz ayı itibariyle gizli işsizlik oranı ise $\% 9.9$ düzeyindedir.

$\mathrm{Bu}$ tarımsal işgücü fazlasınun kaynağı ise topraksız aileler yanında, ağırlıkl olarak 1-50 dekarlık toprak büyüklüklerinde yığılan, sermaye birikimi ve teknolojik gelişme olanakları bulunmayan yarı - geçimlik olarak 
nitelendirilebilecek kırsal nüfustur. Türk tarımında mevsimlik işsizlik ise tarımsal nüfusun \% 70-80'ine ulaşmaktadır (KAZGAN, 1983: 75).

Ancak, Türkiye'de genel kabul gören "işgücü fazlası" tahminlerini ihtiyatla karşılamak ve daha makul ölçülerde tutmak doğru olacaktır. Bunun nedenlerinden biri, resmi istatistiklerin tarım kesimindeki işgücüne ilişkin verilerinin abartılı olmasıdır. Bu, kadınların büyük bölümünün yapay biçimde ücretsiz aile işçisi olarak işgücüne dahil edilmelerinden kaynaklanmaktadır. Bunun yanında, tarım kesimindeki küçük arazi mülkiyeti de, işgücü fazlasına ilişkin tahminlerin ihtiyatla değerlendirilmesini gerektirmektedir. Çünkü arazi mülkiyeti veri iken tarım kesiminden çekilecek işgücü, üretim düzeyinde düşüşlere yol açacaktır. ${ }^{18}$

\section{B. Ücretlilerin Varlığı}

Her sektörde ya da iktisadi faaliyet kolunda olduğu gibi tarımda da işçiler, bir işverene bağhı olarak ücret karşıllı̆ı çalışmakla karakterize olurlar. Ancak, tarım kesiminin kendine özgü şartlarından, bölgesel farklllıklardan veya yetiştirilen üründen kaynaklanan nedenlerle tarım kesimindeki ücretliler kendi içlerinde büyük bir çeşitlilik gösterirler ve diğer kesimlerdekinden çok daha fazla alt kategoriye ayrilırlar. Konumuz açsından temel ayrım, işin süreklilik taşıyıp taşımadığı ölçütüne göre yapılan "sürekli (daimi) işçi" - "geçici işçi" ayrımıdır. Daimi iş̧̧i, en aşağı bir üretim dönemi veya yılı işletmede çalıştırılan kişidir. Buna karşılık geçici iş̧̧i yllın belirli dönemlerinde ve işin yoğunlaştı̆ı zamanlarda çalışan kişidir (KÖYLÜ, 1957: 310). ${ }^{19}$ Türkiye'de tarım kesiminde her iki kategoriyi kapsamak üzere ücretlilerin nicel varlığına ilişkin şeşitli tahminler ile sayım ve anket niteliğinde çalışmalar bulunmaktadır. Çalışma Bakanlığ1, 1940'lı ylllarda Türkiye'de tarım kesiminde çalışanlardan \% 19 kadarının ücretli olduğunu tahmin etmekteydi. Tahmine göre bunlardan \% 61'i erkek, \% 26'sı kadın ve \% 13'ü de çocuklardan oluşmaktaydı (ÇALGÜNER, 1943: 28; ÇD, 1947: 55). ${ }^{20} \mathrm{Bu}$ ve benzeri tahminlerin dışında, değişik tarihlerde yapılan sayım niteliğindeki çalışmaların en önemlileri Genel Nüfus Sayımları ile 1950 Tarım Sayımı, 1952 Tarım Anketi ve 1963 Tarım Sayımı'dır. Ancak bu sayımlara ait veriler, değişik hata ve noksanlarla malûl olduklarından, dikkatli bir biçimde yorumlanmaları ve birlikte değerlendirilmeleri şarttır. Bunların dışında değişik tarihlerde çeşitli kurum ve araştırmacılar tarafından gerçekleştirilen

18 Türkiye'deki gizli işsizlik tartışmaları ve tahminleri konusunda eleştirel bir yaklaşım için, bakınz, (TÜRKAY, 1968: $78 \mathrm{vd}$.).

19 Tarım iş̧ileri geçicilik - süreklilik ölçütü dışında başka ayrımlara da tabi tutulmakta ve her kategorideki iş̧̧ler için bölgeden bölgeye farkh isimler de verilebilmektedir. Bakınız, (ÇALGÜNER, 1943: 35-42; KÖYLÜ, 1957: 310-313).

20 Erkek, kadın ve çocuk iş̧̧lerin 26 vilayet itibariyle oransal dağılımlan, (ÇALGÜNER, 1943: 27-28)'de bulunmaktadır. 
monografiler ile anketler de bulunmaktadır. Bütün bu sayım, anket ve monografilerin birlikte değerlendirilmesi sonucunda tarımsal işgücüne ve ücretlilere ilişkin sağlıklı bilgilere ulaşmak mümkün olabilmektedir.

\section{1955, 1960 ve 1965 Genel Nüfus Sayımlan}

1955, 1960 ve 1965 Genel Nüfus Sayımları, tüm sektörler ve iktisadi faaliyet alanları yanında, tarım kesiminde çalışanların statü dağlımlarına ve bu arada ücretlilerin niceliğine ilişkin bilgiler de vermektedir. Bu değerlendirmelerimizi, 1955, 1960 ve 1965 Sayımları itibariyle yapacağız. Türkiye'de işgücünün statüsüne ilişkin saptamalar 1950 Genel Nüfus Sayımı ile başlamıştır, ancak bu sayımla daha sonrakiler arasında, yaş grupları ve işgücü kategorileri itibariyle uyumsuzluklar bulunmaktadır. ${ }^{21}$

Tablo II: Genel Nüfus Sayumı Sonuçlarna Göre Tarun Kesiminde Işgücünün Statü Dağılumu ve Ücretliler (1955-1965)

\begin{tabular}{|c|c|c|c|c|c|c|c|c|c|}
\hline & \multicolumn{3}{|c|}{ Toplam tarım kesimi } & \multicolumn{2}{|c|}{$\begin{array}{l}\text { Tanı ve } \\
\text { hayvancilik }\end{array}$} & \multicolumn{2}{|c|}{$\begin{array}{l}\text { Ormancilik ve } \\
\text { tomrukşuluk }\end{array}$} & \multicolumn{2}{|c|}{$\begin{array}{c}\text { Avciluk (Kara } \\
\text { ve deniz) }\end{array}$} \\
\hline & 1955 & 1960 & 1965 & 1955 & 1960 & 1955 & 1960 & 1955 & 1960 \\
\hline Iş̧veren & 2781 & 49473 & 21719 & 2663 & 48847 & 62 & 220 & 56 & 406 \\
\hline $\begin{array}{l}\text { Kendi } \\
\text { hesabına } \\
\text { çalışan }\end{array}$ & 2640134 & 2903109 & 3014433 & 2631387 & 2891172 & 2675 & 3277 & 6072 & 8660 \\
\hline $\begin{array}{l}\text { Ücretsiz } \\
\text { aile iş̧̧isi }\end{array}$ & 6551849 & 6097832 & 6311500 & 6549099 & 6094932 & 1845 & 1604 & 905 & 1296 \\
\hline Ücretli & 244235 & 676791 & 376866 & 228568 & 651800 & 12798 & 20830 & 2869 & 4161 \\
\hline Bilinmeyen & 7103 & 10284 & 4486 & 6803 & 9784 & 71 & 226 & 229 & 274 \\
\hline Toplam & 9453205 & 9737489 & 9729004 & 9418520 & 9696535 & 17451 & 26157 & 10131 & 14797 \\
\hline
\end{tabular}

Kaynak: DIE (1965b: 81-82, Tablo 68-69), DIE (1969: 463, Tablo 39)'dan düzenlenmiştir.

21 Yaş olarak, daha sonraki sayımların 15 ve daha yukan yaşlar kategorisi yerine, 5 ve daha yukarı yaşlar esas alınmıştı. Sayımda kullanılan kategoriler de daha sonraki sayımlarla uyumlu değildir. 1950 Sayıminda "aile reisinin işinde ücretsiz", "müesseselerde veya başkasının yanında", "kendi hesabına evinde" ve "kendi hesabına dışarda" kategorileri bulunmaktaydı. Bakınız, (BlGM, 1961a: 358, Tablo 54). 
Tarım kesimindeki ücretlilerin niceliğine ilişkin veriler birçok nedenle fazla tutarlı gibi görünmemektedir. Birinci olarak, sonuçlar, tarım kaynaklı ücretlilerin toplam içerisindeki oranunı 1955-1960 döneminde arttı̆ı̆ı; 1955 yılında \% 2.58 iken, 1960 yılında \% 6.94'e yükseldiğini ortaya koymaktadır. Ancak 1965 yılında oran düşerek \% 3.87 olmaktadır. 1955-1960 dönemindeki artş makul karşlanabilir. 1960-1965 dönemindeki düşüşün bir bölümü de, 1960 döneminde tarım kesiminde ücretli olarak görünenlerin bir bölümünün kentsel kesime yerleşmiş olabilecekleri düşüncesiyle gene makul karşlanabilir. Ancak kanımızca, bu kadar büyük bir düşüş olması güç görünmektedir ve gene kanumızca düşüşün bu kadar büyük olması Genel Nüfus Sayımları'nun uygulama aksaklıklarından kaynaklanmaktadır. Nitekim, 1965 sayımın hemen izleyen yıllarda, İkinci Beş Yllık Kalkınma Planı'nda, tarım alanındaki aktif nüfusun yaklaşık \% 7'sinin ücretle çalıştğı belirtilmektedir (DPT, 1967: 137). Bu bilgi ise 1965 değil, 1960 Genel Nüfus Sayımı'nun sonuçlarıyla tutarlıdır.

İkinci olarak, bu rakamlar, en yüksek olduğu 1960 yılı esas olarak alınsa bile, yukarıda 1940 'lı yıllar için verilen resmi tahminden ve aşağıda verilecek olan 1950 ve 1963 Tarım Sayımlarında görülen ücretli sayılarından azdır ve yorumlanmaya muhtaçtır. Kanumızca, rakamların düşüklüğü, Genel Nüfus Sayımlarının metodolojisinden kaynaklanmaktadır. Çünkü, her üç sayımda da işgücünün statüsü, sayımdan önce gelen son hafta itibariyle saptanmaya çalışılmıştır. Oysa tarımsal faaliyetler, doğası gereği yılın belirli dönemlerinde yoğunlaşmaktadır ve nüfus sayımlarının yapıldığı Ekim ayı da Türkiye şartları açısından tarım kesimininde çalışmaların yoğunluğunu kaybettiği bir aydır (KARAHASANOĞLU, 1970: 2, 10-11). Bu nedenle de özellikle sayım öncesi haftada çalışmamakla birlikte, yllın daha önceki dönemlerinde faaliyette bulunan geçici tarım işçilerinin kapsanmaması söz konusu olmaktadır. Bu durumda kapsanan tarım iş̧̧leri ise büyük ölçüde süreklilik niteliği taşıyanlar olmalıdır ve Aksoy'un belirttiği gibi, rakamları tarım iş̧̧ilerinin tümünden çok, sürekli tarım işçileri için geçerli olarak kabul etmek daha doğru olacaktır (AKSOY, 1971: 116). Aşağıda ele alınacak Tarım Sayımlarında ise sonuçlar son hafta değil, son yıl itibariyle değerlendirildiği için, iş̧̧i sayısı çok daha yüksek çıkmaktadır.

\section{1950 ve 1963 Tarım Sayımlan İle Diğer Anket ve Araştırmalara Göre Ücretliler}

Ücretlilerin sayısına ilişkin daha ayrıntlı bilgiler ise 1950 ve 1963 yıllarında gerçekleştirilen tarım sayımlarından elde edilebilmektedir. Aşağıdaki ilk tabloda, 1950 Tarım Sayımı'na göre tarım kesimindeki geçici ve sürekli işçilerin miktarı görülmektedir. Buradaki iş̧̧ilerin hepsi kırsal kesim kaynaklı 
olup, ikinci ve üçüncü sütunlarda şehir ya da köy olarak gidilen yer belirtilmektedir. Ancak gidilen yerlerin bire bir oranında tarım ve tarım dışı faaliyet alanlarına tekabül etmediği belirtilmelidir. Kentsel bölgelerde tarım işçiliğine gidilebildiği gibi, köylerde tarım dışı faaliyetlerde de çalı̧̧labilmektedir. Genellikle düşünüldüğü gibi, kırsal kesimde sadece tarımsal faaliyetlerde bulunulmamakta, bunun dışında faaliyetler de yer almaktadır. Dönem içerisinde ve değişik tarihlerde yapılan araştırmalar, kırsal kesimde tarım dışı faaliyetlerde çalışanların oranının \% 15 dolaylarında olduğunu göstermektedir. Örneğin, 1945 Köyler İstatistiği ve 1950 Ziraat Sayımı köylerde nüfusun \% 15 'inin ağırlıklı olarak dokumacllk olmak üzere el ve ev sanatlarında çalıştığın ortaya koymaktaydı (BIGM, 1948: 5, Tablo 12; BIUM, 1956: 122). 1963 Tanı Sayımı sonuçlarına göre de, tarım dışı olarak nitelendirilebilecek işlerde çalışanların oran $\% 12$ dolaylarındayd 1.22

Tablo III: 1950 Tarum Sayımu Sonuçlarnna Göre Tarm Işçilerinin Sayısı

\begin{tabular}{|l|r|r|c|}
\hline & Şehir & Köy & Toplam \\
\hline Kazanç için giden iş̧̧iler & 181908 & 559492 & 741400 \\
\hline Daimi ziraat işçiliği yapanlar & 63521 & 251303 & 314824 \\
\hline Toplam & 245429 & 810795 & 1056224 \\
\hline
\end{tabular}

Kaynak: KANBOLAT (1963: 59).

Tablodan, 1950 y1lında tarım kaynaklı işçilerin büyük bölümünün, yaklaşık \% 70'inin geçici (mevsimlik) iş̧̧i olduğu anlaşılmaktadır. ${ }^{23}$ Sürekli işçilerin oranı ise sadece \% 30 'dur. Geçici ya da sürekli iş̧̧ilik yapanların sadece $\%$ 23.23'ü şehirlere giderken, köylere gidenlerin oran \% 76.77'yi bulmaktadır. Bir başka araşturma da bu sonuçları doğrulamaktadır. 1950'li yılların başında Siyasal Bilgiler Fakültesi tarafından gerçekleştirilen "Türkiye'de Ziraî Makinalaşma" araştırması, tarımda makinalaşma sonucu işsiz kalanların beşte birinin şehre veya kasabaya gittiğini, beşte dördünden fazlasının ise köylerinde

22 (DIE, 1965a: 72-73)'teki verilerden hesaplanmıştır. 1948, 1949 ve 1952 tarihlerinde gerçekleştirilen diğer sayım ve anketler de, köylü aileler içerisinde çiftçi olmayanların oranının \% 13.6 ila \% 16.5 arasında değiştiğini ortaya koymaktadır. Bakınız, (BIUM, 1953: 6, Tablo 2).

23 Bunlar, sürekli ikametgâhları nüfusu 2000 'in altında olan yerleşim birimlerinde olan ve iş̧̧ilik yapmak üzere yılda en az 30 gün buralardan ayrılan kişilerdir. 
kaldığını ortaya koymaktaydı (SBF, 1954: 101). Iş ve Iş̧̧i Bulma Kurumu'nun verileri de, kırsal kesimde kalanların sayısına ilişkin bilgi vermektedir. 1958 yılında Çukurova bölgesinde sadece Kurumun işe yerleştirdiği iş̧̧i sayısı 120 619'dur (IIBK, 1959: 72). ${ }^{24}$ Kurum dışında elciler araclığıyla işe yerleştirilen iş̧̧ilerle birlikte toplamın 200000 'e ulaşacağ tahmin edilmektedir. ${ }^{25}$ Aileleriyle gelen ve tarlalarda çalışan çocuklarla bu rakam daha da büyüyecektir. 1962 yll itibariyle Ege Bölgesi'ne çalışmak üzere gelen mevsimlik tarım iş̧̧ilerinin sayısı da 100000 dolaylarındadır. ${ }^{26}$ Kurumun 1960 yllında tüm Türkiye'de işe yerleştirdiği tarım iş̧̧isi sayısı ise $368735^{\prime}$ 'tir (AKSOY, 1969: 46).

Bu durumda, yukarıda belirttiğimiz gibi, şehir tarım dışı faaliyetlerle; köy ise tarımsal faaliyetlerle özdeşleşmemesine karşın, kazanç için giden işçilerin (geçici işçilerin) büyük çoğunluğunun tarımsal faaliyet alanlarında çalıştığı çıkarsanabilir (KANBOLAT, 1963: 59). Bu oranlar, yukarıda yaptığımız değerlendirmeler çerçevesinde yorumlanmalıdır. Bu, 1950'li ylllar itibariyle, henüz kentlerin bu işgücünü çekecek düzeyde gelişmemiş ve çekici güce kavuşmamış olmaları ve ulaşım olanaklarının gelişmemiş olması yanında, tarım kesiminin de şöyle ya da böyle ücretli işgücünün büyük bir bölümünü hâlâ istihdam edebildiğini göstermektedir.

Aşağıdaki tabloda ise nüfusu 5000 ve daha az olan yerleşim birimlerinde gerçekleştirilen 1963 Tarım Sayımı sonuçlarına göre işgücünün statüsü ve bu çerçevede ücretlilerin miktarı verilmektedir. Tablonun, bu yerleşim birimleri itibariyle, tarımsal olduğu kadar tarım dışı faaliyet alanlarına ilişkin bilgi de verdiğine dikkat edilmelidir. Buna göre iktisaden faal nüfusun 88.18 'i tarımsal faaliyetlerde çalışırken, \% 11.82'si tarım dışı faaliyet alanlarında çalışmaktadır.

Her iki sayım itibariyle yapılması gereken bir değerlendirme, tarım iş̧ilerinin sayısının aynı dönemlerdeki topraksız aile sayısını kat kat aştığıdır. 1950 Tarım Sayımı sonuçlanna göre toplam 2760304 aileden 336860 's, yani \% 12.20'si tümüyle topraksızdır (KANBOLAT, 1963: 33). 1963 Sayımı'na göre ise toplam 3514476 aileden 308 899'u, yani \% 8.79'u topraksızdır (DIE, 1965a: 6). Bu durumda her iki yllda da, tarım işcilerinin sadece topraksız ailelerden oluşabilmesi için her aileden yaklaşık 3.5 kişinin tarım iş̧̧iliği yapması gerekmektedir. Bu mümkün olmadığına göre, rakamlar, topraksız aileler yanında özellikle küçük arazi mülkiyetine sahip geçimlik düzeydeki aile işletmesi sahiplerinin ya da aile fertlerinin de geniş ölçüde geçici işçiliğe

24 Mükerrer yerleştirmeler hesaba katılırsa, iş̧̧i sayısının 70000 civarında olduğu tahmin edilmektedir. Bakını, (IIBK, 1959: 73).

25 Mükerrer yerleştirmeler hesaba katılırsa, iş̧̧ sayısının $100000^{\circ} \mathrm{i}$ biraz geçeceği tahmin edilmektedir. Bakınız, (IIBK, 1959: 73).

26 (IIBK, 1962: 25-28)'deki bilgilerden hesaplanmıştır. 
yöneldikleri biçiminde yorumlanmalıdır. ${ }^{27}$ Mevsimlik iş̧̧ilerin önemli bir kısmını küçük bir toprak parçasına sahip olan fakir mülk sahipleri teşkil etmektedir (AKSOY, 1969: 42).28 1940'h yllarin sonunda Orta Anadolu'da yapılan bir araştırma, "işletmelerin üçte ikisinin istihsalleri sahiplerinin beslenmesini temin etmeye bile kifayet etmeyecek derecede küçük" olduğu için, "Orta Anadolu çiftçilerinin mühim bir kusmunun bizzat kendi ziraatleriyle yaşayamamakta, hayatlarını idame ettirebilmek için büyük ölçüde geçici işlere muhtaç" olduğunu ortaya koymaktadır (VON FLÜGGE, 1948-1949: 133). Çalışmada, bu geçici işlerin ise tanm kesiminde olduğu kadar küçük sanatlarda ve veya sanayide çalışmak biçiminde tezahür ettiği belirtilmektedir (VON FLÜGGE, 1948-1949: 134).29 1960'ı yıllarda yapılan ve iç göç olgusunun coğrafi boyutların ortaya koyan bir çalışma da; küçük arazi sahiplerinin, örneğin 1-20 dönüm arasındaki arazileri işleyen çiftçi ailelerinin yoğun olduğu illerin, iç göçlerde de önemli payı olduğunu göstermektedir. ${ }^{30}$ Değişik tarihlerde Ankara'nun geniş ölçüde göç alan gecekondu bölgelerinde yapılan araştırmalar, gọ̈ nedenleri arasında topraksızlik yanunda toprak yetersizliğinin de bulunduğunu ortaya koymaktadır. Yasa'nın 1962 tarihli araştırmasına göre "topraksızlık ve yetersizliği" gö̧̧ nedenleri arasında \% 46, işsizlik ise \% 14'lük bir orana sahiptir (YASA, 1966: 73, Çizelge 18). ${ }^{31}$

Aşağıda ise 1963 Tarım Sayımı sonuçlarına göre ücretliler ve diğer işgücü statülerinin nicelikleri verilmektedir.

27 Talas'ın 1950"li yıllar için yaptığı değerlendirmeyle, "Bunların çoğu aynı zamanda küçük toprak sahipleridir. Fakat bu topraklardan elde eyledikleri gelir kendilerini ve ailelerini geçindirmeğe kafi gelmez.Kendilerinin istihsal edemedikleri bir kısım ihtiyaçların pazardan tedarik edebilmek için kendi topraklarındaki işlerini gördükten sonra muayyen bölgelere çalışmaya giderler. Buralarda umumiyetle pamuk, tütün işlerinde çalışırlar. Mevsimle beraber iş sona erince köylerine dönerler. Işler genel olarak üç-dört ay devam eder." Bakınız, (TALAS, 1960: 37).

28 Kelimenin bu anlamında, Erkul, geçici tarım iş̧̧ileri için, "çiftçi - ziraat iş̧̧isi" terimini kullanmaktadır. Burada çiftçi sözcüğü, kişinin tarım yaptığı bir araziye sahip olmasına, ziraat işçisi sözcüğ̈ ise yılın belirli dönemlerinde geçici tarım iş̧̧iliği yapmasına atıfta bulunmaktadır. Bakınız, (ERKUL, 1967: 43).

29 Çalgüner' in 1943 ylında Seyhan Milli Mensucat Fabrikasinda yapılan bir araştırmaya dayalı değerlendirmeleri, iş̧̧lerin en az \% 50"sinin "mülk sahibi ve ziraatle ilgili" olduklarını ortaya koymaktaydı. Bakınız, (ÇALGÜNER, 1943: 19).

30 Bakını, (TÜMERTEKIN, 1968: 52). Tümertekin, Istanbul'un sanayi bölgesi Bomonti'yi değerlendirdiği çalışmada, ayı sonucu Bomonti örneğinde vurgulamaktadır. Bakınız, (TUMERTEKIN, 1967: 57).

31 Benzeri oran ve değerlendirmeler için, bakınız, (KIRAY, 1972: 567). 
Tablo IV: 1963 Tarm Sayımu Sonuçlarına Göre Iktisaden Faal Nüfusun Is Yerindeki Mevkil

\begin{tabular}{|l|c|c|c|c|c|c|}
\hline & \multicolumn{2}{|l|}{ Tarım Kesimi } & \multicolumn{2}{l|}{ Tarım dışı kesimler } & \multicolumn{2}{l|}{ Toplam } \\
\hline $\begin{array}{l}\text { Is yerindeki } \\
\text { mevkii }\end{array}$ & $\begin{array}{l}\text { Sayı } \\
\text { içindeki } \\
\text { oran \% }\end{array}$ & $\begin{array}{l}\text { Sayı } \\
\text { Toplam } \\
\text { içindeki } \\
\text { oran \% }\end{array}$ & $\begin{array}{l}\text { Sayı } \\
\text { içindeki } \\
\text { oran \% }\end{array}$ \\
\hline $\begin{array}{l}\text { Işveren } \\
\text { Ücretli }\end{array}$ & 569331 & 9.46 & 38069 & 4.72 & 607400 & 8.90 \\
\hline $\begin{array}{l}\text { Ücretsiz aile } \\
\text { iş̧̧isi }\end{array}$ & 3054803 & 50.73 & 79989 & 9.91 & 3134792 & 45.91 \\
\hline $\begin{array}{l}\text { Kendi } \\
\text { hesabına }\end{array}$ & 1972304 & 32.75 & 148470 & 18.40 & 2120774 & 31.05 \\
\hline Toplam & 6021431 & 100.00 & 806843 & 100.00 & 6828274 & 100.00 \\
\hline
\end{tabular}

Kaynak: DIE (1965a: 70-71).

Tablodaki bazı rakamlar, verilerin ihtiyatla değerlendirilmesi gerektiğini ortaya koymaktadır. Tarım kesiminde işveren sayısı 569331 olarak gözükürken, işçi sayısı sadece $424993^{\prime}$ tür. Tarım kesiminde yılın bazı dönemlerinde kendisi ücretli olarak çalışan bir kişinin, yllın başka dönemlerinde ücretli işçi istihdam etmesi; yani aynı kişinin farklı statü kategorilerinde yer alabilmesi mümkün olabilmekle birlikte, rakamların çok tutarsız olduğu söylenmelidir. Bu aksaklıklar bir yana, 1963 Tarım Sayımı sonuçlarına göre ücretlilerin iktisaden faal nüfus içerisindeki oranı \% 14.14 olarak görünmektedir. ${ }^{32}$ Ücretliler içerisinde tarım dışı faaliyet alanlarında çalışanların oranı ise \% 55.98'dir. Iki sayımın metodolojisi tam anlamıyla çakışmadığı için net sonuçlar üretilemese de, 1950-1963 döneminde, kırsal kesim kaynaklı işçilerin tarim dışı faaliyet alanlarında çalışma oranının ciddi ölçüde yükseldiği söylenebilir. Bu, büyük ölçüde kentsel kesimde çalışmanın artması biçiminde olmuştur ve iki sayım arasında geçen 13 ylllık süre içerisinde, kentlerin ve tarım dışı faaliyct alanlarının gelişmesi ve çekim gücünün artmasıyla bağlantılıdır. Ulaşım

32 Bu oran, Iş ve Iş̧̧i Bulma Kurumu'nun 1950'li yulların sonunda değişik bölgelerde yaptı̆̆ı işgücü anketlerinin sonuçlanyla tutarlı görünmektedir. 1957 yılında yapılan Karadeniz Bölgesi Işgücü Anketi, çalışmak için köy dısına gidenlerin işgücüne oranının \% 16.6 olduğunu ortaya koymaktaydı. Bakınz, (IlBK, 1957: 21). Akdeniz Bölgesi'nde 1958 yılı itibariyle ayn oran \% 12'dir. Bakınz, (IlBK, 1959: 28). Dışarıya çok gọ̈ vermeyen Ege Bölgesi'nde ise oran en düşük olup, \% 7'dir. Bakınız, (IIBK, 1962: 44). 
olanaklarındaki gelişme de "iletici" bir faktör olarak bu eğilimi huzlandırmıs olmalıdır. Tarım dışı kesimlere ilişkin statü dağ lımı ise kırsal kesimde tarım dışı faaliyet alanlarınn artmasınn ancak küçük bir etkide bulunabileceğini göstermektedir.

Ancak, bu noktada, istatistiklerde görünmeyen kadınlarla ilgili bir duruma dikkat çekmek gerekir. Kırsal kesimde, ağırlıklı olarak tarım dişı alanlarda ve halı dokumacılığı gibi faaliyet kollarında çalışan ve sayıları hiç de az olmayan bir kadın nüfus, sayım yöntemlerinden dolayı, az önce verdiğimiz kursal kesimde fakat tarım dışı faaliyetlerde çalışan nüfus içerisinde gözükmemektedir. Çalışma koşulları itibariyle ücretli olan ya da ücretlilik benzeri bir durum gösteren bu kadınlar, büyük ölçüde tarımsal faaliyetlerde ve ücretsiz aile iş̧̧iliği içerisinde görünmektedirler. ${ }^{33}$

Hem 1950, hem de 1963 sayımlarına göre tarım kesimindeki ücretlilerin sayısı 1000000 dolaylarında görünmektedir. Ancak, bu büyüklüğün içinde, sürekli iş̧̧ilerden çok geçici iş̧̧lerin bulunduğu göz ardı edilmemelidir. İ̧ ve Iş̧̧i Bulma Kurumu'nun 1950'li yılların sonunda gerçekleştirdiği işgücü anketleri, geçici iş̧ilerin, yılın ne kadarlık bir bölümünde çalıştıklarına ilişkin bilgiler vermektedir. Akdeniz Bölgesinde gerçekleştirilen ankete göre işçilerin dışarıda kalma süreleri, gidilen bölgeye göre değişmekle birlikte ortalama 117 gün yani dört ay dolaylarındadır. ${ }^{34}$ Karadeniz Bölgesi anketinde ise, ortalama dişarıda kalma süresi 178 gündür (IIBK, 1957: 23). ${ }^{35}$

Sorunun bir başka önemli yönü ise tarım kesiminde özellikle geçici işçi olarak çalışanların hangi iktisadi faaliyet kollarında ve hangi yerleşim birimlerinde istihdam edildiklerine ilişkindir. Konuya ilişkin olarak, 1950'li yllarda Iş ve Iş̧̧i Bulma Kurumu'nun yaptığ bölgesel işgücü anketleri; geçici iş̧̧ilerin yöneldikleri faaliyet alanlarının bölgeden bölgeye değiştiğini ortaya koymaktadır. Karadeniz Bölgesi Anketi'nde yönelim ağırlıklı olarak imalat sanayiine (\% 60-70) ve hizmetler kesiminedir. (\% 10) Bunu küçük oranlarda olmak üzere diğer faaliyetler izlemektedir (IIBK, 1957: 26). Buna karşllk Akdeniz Bölgesi'nde tarım işleri \% 82.9'luk bir ağırlığa sahip bulunmakta, bunu \% 8.3 ile inşaat işleri ve küçük oranlarda olmak üzere diğer faaliyetler izlemektedir (IIBK, 1959: 49). ${ }^{36}$

33 Konuya ilişkin kapsamlı bilgi ve değerlendirmeler için, bakınız, (MAKAL, 2001: 128-132).

34 (IlBK, 1959: 28)'deki verilerden hesaplanmıştır.

$35 \mathrm{lki}$ anket arasındaki farklılık, Akdeniz Bölgesi'ndeki iş̧̧ilerin ağırlıklı olarak tarımsal faaliyetlere, Karadeniz Bölgesi iş̧̧ilerinin ise tarımla birlikte, diğer faaliyet alanlarına yönelmelerinden kaynaklanmaktadır.

36 Ankara Üniversitesi Siyasal Bilgiler Fakültesi tarafından Türk Iktisadi Gelişmesi Araştırma Projesi çerçevesinde 1961 yulında gerçekleştirilen bir alan araştırması da, köy dışna geçici olarak giden iş̧̧ilerin hangi iktisadi faaliyet kollarında çalıştıklarına ilişkin bilgiler vermektedir. Buna göre ağırlıklı olan tarım ve inşaat işlerinin yanında; fabrika 


\section{Tarım Kesimi ve I̧̧ Göçler}

Tarım kesiminde birçok faktörün etkisi altında oluşan işgücü fazlası; sürekli ya da geçici işç olarak; gerek kursal, gerekse kentsel kesimlerde iş olanaklarının bulunduğu yerlere akmaktadır. Bu akış bir yerde süreklilik kazanarak iç göçe dönüşmektedir. Ancak bu göç "...yalnızca bir yerden ötekine yataysal hareket değildir. Giderek, belirli bir sinıf yapısındaki, örneğin modernleşme öncesi toplumlarda, dikeysel hareket bile değildir. Ama daha önemlisi, gö̧ olgusu, üretimi ve buradaki ilişkileri temelden değiştiren bir süreci ifadelendirmektedir." (KIRAY, 1972: 566-567). Bu nedenle, bu karmaşık oluşum, dönem içerisinde Türkiye'nin gerek kursal, gerekse kentsel kesimde geçirdiği yapısal dönüşümler şerçevesinde anlaşılabilir. Kırsal ve kentsel kesimlerdeki dönüşümler ise doğası gereği birbirlerine bağhdır ve ayrı ayrı anlaşılamazlar.

İ̧ göç olayına klasik yaklaşım, yaşananları, genellikle "kırın iticiliği kentin çekiciliği" kavram ikilisi çerçevesinde ele almaktır. Itici güçler, "köylüyü toprağından, tarımdan ayrılmaya zorlayan koşullardır. Tarımda verim azlı̆̆ı, tarımsal gelirin yetersizliği, bu yetersiz gelirin ve tarımdaki toprak mülkiyetinin dengesiz dağılışı, tanm topraklarının çok parçalanmış olması ve tarımsal makinalaşmanun, belli ölçülerde, tarlada çalışanları işsiz bırakması, iklim koşulları ve toprak erozyonu, bu itici güçlerin başlıcalarıdır." (KELEŞ, 1978: 37). Çekici güçler ise "Nüfusu kentlere çeken etkenlerdir. Bunlar, kısaca, tarım dışı kesimlerde yaratılan iş olanakları diye tanumlanabilir. Bu güçlerin başında sanayileşme gelir." (KELEŞ, 1978: 38). Kentsel kesimdeki sağlık, eğitim, eğlence ve benzeri olanaklar da çekici güçler arasındadır.

Bu yaklaşım genel olarak, göç üzerinde etkili olan faktörleri ayrıştırma ve çözümleme açısından yararlı gibi görünmektedir. Ancak, yaklaşım içerisinde ayrıştırılan faktörler değerlendirilirken, aralarındaki diyalektik bütünlük biraz kayboluyor gibidir. Bir anlamda ağaçlar somutlaştırilırken, orman gözden kaybediliyor gibidir. Kurdan kente göç iticilik - çekicilik ekseninde ele alınamayacak kadar karmaşıktır ve Tekeli'nin ifadesiyle ancak kabaca doğru olan, aşırı ölçüde basitleştirilmiş olan bu yaklaşım, "kırda olan karmaşık dönüşümü açıklamakta yetersiz kalır." (TEKELI, 1982b: 86). Bu nedenle, bu kavram ikilisinin sağladığı çözümleme olanakları kullanılmakla birlikte; eleştirel bir yaklaşımın benimsenmesi de yararlı olacaktır.

Bir defa, kırın iticilik ve kentin çekicilik derecelerinin göreli olup, değişik nüfus ve işgücü kategorilerini farklı biçimde etkileyebileceği düşünülebilir. Örneğin, kırsal kesimde tümüyle topraksız köylü kategorisinde olan ve bu 
kesimde iş bulamayan kişiler açısından, elbette kırın iticiliği başat olacaktur. Ama belirli bir arazi mülkiyetine sahip olduğu halde kırsal kesimde geçimlik üretim düzeyinde bulunan kişiler, muhtemelen kırda kalma ya da kente göçme tercihlerini, daha geniş bir yelpazede belirleme olanağına sahip olacaklardır ve onların tercihlerinde hem iticilik, hem de çekicilik ögeleri farklı oranlarda etkili olacaktır. Ayrıca, kırın iticiliği ile tarımsal faaliyetlerin iticiliği arasında da bir ayrım yapmak zorunlu olmaktadır. Çünkü, süreç içerisinde kursal kesimdeki gelişmeler de homojen değildir ve bu kesimde tarım dışı faaliyetlerde meydana gelen artı̧ ve bunun sağladığı istihdam olanakları, insanları kurda kalmakla birlikte, tarım dışı faaliyetlerde çalışmaya itebilecektir. ${ }^{37}$ Bazı nüfus kategorileri ise hem kırla hem de kentle bağlantıların sürdürmekte, ailenin bir bölümü kırda bir bölümü kentte yaşayabilmektedir. Ayrıca kırla kent arasındaki bağlantıyı sağlayan ulaşım olanaklarının genişlemesi, iticilik ya da çekiciliğin her ikisinin de içerisinde yer almayan ama kırla kenti birbirine bağlayan ara bir değişen olarak belirleyici öneme sahip olmuştur. ${ }^{38}$

Bu eleştiriler saklı tutulmak kaydıyla, şüphesiz tarım kesiminde ortaya çkan gelişmeler, en genel çizgileriyle tarım kesiminin iticiliğini artırmaktadır ve döneme ilişkin değerlendirmeler kırsal kesimin iticiliği - kentsel kesimin çekiciliği kavram seti içerisinde ağırlığın kırsal kesimin iticiliğinde olduğunu göstermektedir. ${ }^{39} 1950$ 'lerin başı itibariyle ağırlığın kırsal kesimin iticiliğinde olduğu, ancak zaman içerisinde tedrici bir biçimde kentsel kesimin çekiciliğinin arttığını söyleyebiliriz. ${ }^{40}$ Kentlerin çekim gücüne ve bu gücün kaynaklarına ilişkin olarak ise çok sayıda faktörün göz önüne alınması icap eder. Bu faktörlerden biri, kırsal ve kentsel kesimler arasindaki gelir ve ücret farklılıklarıdır. Türkiye'de kırsal kesimle kentsel kesim arasindaki gelir farklılıkları, inceleme dönemimize özgü olmayıp, Türkiye'de her dönemde bu farklılıklar gözlenmektedir. Örneğin imalat sanayiinde gelir / istihdam olarak hesaplanan verimlilik, tarım kesimindekinin 1925 yllında 5.4 katı, 1940 yllinda 6.9 katı, 1950 yllinda 4.8 kat1, 1960 yılinda ise 4.2 katıdir (BULUTAY, 1995: 279, Tablo 9.I). Genel gelir farklllkkları dışında soruna sadece ücret düzeyleri açısından yaklaşıldığında da, iki kesimdeki ücretler arasında ciddi farklllıklar bulunmaktadır. Örneğin, aylık TL. olarak 1940-1949 dönemi ortalama ücret

37 Kırsal kesimde ama tarım dışında, hah dokumacılığı gibi alanlarda çalışma bunlar arasindadir.

38 Keleş, bunu, taşımım olanaklarındaki gelişme olarak tanımlamakta ve "iletici" güçler olarak nitelemektedir. Bakınız, (KELEŞ, 1978: 37).

39 Örneğin Kepenek'e göre, "Kentleşmenin başlıca nedeni kırsal kesimin pazara açılması ve traktör kullanımı sonucu işgücünü itmesidir. Denilebilir ki kentleşme süreci, kentlerdeki iş olanaklarının gelişimine, kentlerin iş gücünü çekmesine bağıml bir olgu değildir." Bakınız, (KEPENEK, 1987: 109).

40 Tümertekin ise 1960' larda yaptı̆̆ değerlendirmede, şehirlerin çekiciliğini "daha yeni bir olay" olarak nitelemektedir. Bakınız, (TÜMERTEKIN, 1968: 55). 
rakamları; tarımda 61.56 , imalat sanayiinde 90.35 , inşaatta 85.60 , ticarette 121.80'dir. 1950-1959 döneminde ise ortalama olarak tarımda 153.5, imalat sanayiinde 223.9, ticarette 301.6'dır (BULUTAY, 1995: 301, Tablo 9.G). Dönem itibariyle tarım kesimindeki ücret ortalamalarınun, sanayi kesimindekinin \% 68.56 'sı, ticaret kesimindekinin ise \% 50.90'ı olduğu görülmektedir. Bu veriler ışığında, kır - kent gelir ve ücret farklılıklarının kentsel kesimin çekiciliği üzerindeki etkilerini yok saymak, kanımızca olanaklı değildir. Bulutay, bu farklulıkların 1950 öncesi dönemde daha da büyük ölçüde var oldukların belirterek, gelir ve ücret farklulıklarının etken, açıklayıcı bir değişken olarak kabul edilemeyeceğini savunmaktadır (BULUTAY, 1995: 122). Ancak, kanımızca, bu farklılıkların 1950 öncesi dönemde etken olmayışı, 1950 sonrası dönemde de etken olmadığı anlamma gelmez. Çünkü 1950 öncesi döneme ilişkin olarak, çözümlemeye daha başka faktörleri de hesaba katmak icap eder ve ulaşım olanaklarının yetersizliği, kentsel kesimde iskân sorunu bunlar arasındadır. 1950 sonrası dönemde bu olanakların fazlalaşmasıyla, gelir farklılıklarının çekim üzerindeki etkileri de artmıs olmalıdır. ${ }^{41}$

Yaplan araştırmalar, kentsel kesimin çekiciliğinin büyük ölçüde sanayileşmeye bağlı olduğunu göstermektedir. 1960'lı yıllarda yapılan iç göçlerin coğrafi boyutlarına ilişkin bir çalışma, ülkenin sanayi tesisleri haritasıyla iç gö̧ alma arasında yakın bir bağlantı olduğunu ortaya koymaktadır. ${ }^{42}$ Bu çekim gücü, büyük ölçüde sürekli gelir getiren bir iş sahibi olma beklentisinden kaynaklanmakta; gelirin sürekliliği, gelirin düşüklügüünü ikinci plana itmektedir. Ayrica, kentsel kesimdeki gelir düzeyi düşük dahi olsa, bunun kırsal kesimde elde edilmekte olan sınurlı gelirden gene de daha yüksek olması beklenir. Bunun yanı sıra, kentsel - kırsal kesim gelirleri arasındaki farklılığın, sadece çalışılan dönemin geliri değil, geleceğe yönelik gelir beklentileri açısından da değerlendirilmesi gerekir. Tarım dişı faaliyet alanları itibariyle, Türkiye'de 1945 yllında İş̧i Sigortalan Kurumu'nun ve tedrici bir biçimde değişik sosyal güvenlik kollarının kurulmasıyla gelişen sosyal güvenlik olanaklarının varlığı da, bu kaymaỳı olumlu yönde etkilemektedir. Eğitim olanaklarının kırsal kesime göre genişliği ve yeni gelişmekte olan kentlerin sunduğu, örneğin sağlık gibi olanakların varlığı da, kentlere kayışı teşvik edici önemli nedenler arasındadır. ${ }^{43}$ Bu koşullar altında, Türkiye'de işgücü akımı, önceleri geçici ve ağırlıklı olarak tarım kesimi içerisinde iken, zamanla ve özellikle 1960 sonrası dönemde süreklilik niteliği kazanacak ve kentlere

41 Cillov'a göre, "...yol şebekesinin ıslahı, gö̧ hareketini geniş ölçüde teşvike yardımcı olmuştur." Bakınz, (CILLOV, 1972: 93).

42 Bakını, (TÜMERTEKIN, 1968: 57-58).

43 Tarım kesiminin itmesine, kentsel kesimin çekmesine ilişkin faktörlerin teori ve Türkiye deneyimi itibariyle geniş bir değerlendirmesi için, bakınz, (BULUTAY, 1995: 121-126). 
yönelecektir. Bu yönelimin boyutları, kırsal ve kentsel kesim nüfuslarındaki değişmeden izlenebilmektedir. 1945 yulı itibariyle il ve ilçe merkezlerinde yaşayanların oran \% $24.9 \mathrm{iken}, 1950$ 'de $25.0^{\prime} \mathrm{a}, 1955^{\prime}$ te $28.8^{\prime} \mathrm{e}, 1960^{\prime}$ ta $\% 31.9^{\prime} \mathrm{a}$, 1965 'te ise \% 34.4'e yükselmektedir. Koşut biçimde bucak ve köylerde yaşayanların oran ise ayn yıllar için surasıyla \% 75.1, \% 75.0, \% 71.2, \% 68.1 ve \% 65.6 olmaktadır (DIE, 1977: 30, Tablo 22). 1950-1960 dönemi, kentli nüfus oranında en büyük artışın sağlandığı dönem olmaktadır (ClLLOV, 1972: 92). Kırsal kesimde doğal nüfus artı̧ oranı kentsel kesimden daha yüksek olduğu için, sonuçlar kurdan kente göç olgusunu açık bir biçimde ortaya koymaktadır. 1966-1967 yılında yapılan bir nüfus araştırmasına göre doğal nüfus artı̧ oranı, Türkiye ortalaması itibariyle binde $24.1 \mathrm{iken}$; kentsel kesimde binde 16.8, köysel kesimde ise binde 27.2 oranundayd. (SSYB, 1970: 38, Tablo 15).

\section{C. İ̧ Göçün Kentteki Istihdama Yansımaları}

Ancak, kurdan kente göçün istihdam boyutuna ilişkin olarak ihtiyatlı yorumlar yapmakta fayda vardır. Türkiye'de kentlere göç edenlerin büyük bölümünün formel sektörde ve süreklilik - iş güvencesi - daha yüksek ücret koşulları altında istihdam edildiğini söylemek olanaksızdır. Çünkü, kentsel kesimin gelişme hızı, kırsal kesimden gö̧̧enlere bu tür iş olanakları sağlayamayacak kadar düşük boyutlarda kalmaktadır. Bunun sonuçlarından biri, gö̧ edenlerden bir bölümünün işsiz kalması olmaktadır. Konuya ilişkin çalışmalar, bu kesim içerisinde, kırsal kesimde olduğu gibi işsizlik oranının yüksek olduğunu ortaya koymuştur. İstanbul'da yapılan bir araştırmaya göre, gecekondu bölgelerinde sürekli bir işi bulunmayan ailelerin oran \% 34 'ü bulmaktadır. ${ }^{44}$ Bir diğer sonuç ise gọ̈ edenlerden büyükçe bir bölümün marjinal işlerde çalışmalarıdır. 1950'li ve 1960'lı yıllarda Ankara'nın gecekondu bölgelerinde yapılan araştırmalar bu nüfusun çalıştıkları işler konusunda bilgiler sunmaktadır. Ibrahim Yasa'nu 1962 yilında Ankara'nun tüm gecekondu bölgelerinde yaptı̆̆ alan araştırmasının sonuçlarına göre çalışılan işlerin oran şöyledir: Vasıflı işçi - zanaatçi \% 27.0, düz iş̧̧i (amele) \% 11.5, müstahdem \% 15, küçük esnaf - tüccar \% 17.0, çiftçi - hayvancı \% 1, irat sahibi \% 1, memur \% 14.5, işsiz \% 3.5 (YASA, 1966: 123, Çizelge 53).45 1950'li ve 1960'lı yllarda Ankara'nın gecekondu bölgelerinde yapılan diğer araştırmaların sonuçları da, bu bölgeler nüfusunun genellikle küçük çaplı ticaret, esnaflık, becerisiz iş̧̧ilik ve küçük memurluk ile marjinal işlerde çalıştıklannı ortaya koymaktadır. ${ }^{46}$ Işportaclık, araba siliciliği vb. işlerden oluşan marjinal işler kategorisinin temel özellikleri ise formel sektörden farklı olarak; devamlılık niteliği taşımaması, düşük verimlilık,

44 Bakını, (KELES, 1978: 87-88).

45 Kıray'ın 1970 araştırması da benzer sonuçlar vermektedir. Bakınız, (KIRAY, 1972: 567).

46 Bu araştırma ların bulgularına ilişkin bir özet için, bakınız, \$(ENYAPILI, 1985: 182-184). 
işe giriş-çıkış engellerinin olmaması, düşük sermaye gerektirmesi, yüksek bir iş değiştirme oranına sahip olmasıdır. ${ }^{47}$ Bu kesimde işgücü içerisindeki işverenlik - kendi kesabına çalışma ve işçilik statüleri de bazan birbirlerinden net hatlanyla ayrılıyor olmayıp, statüler arası geçişlilikler ortaya çkabilmektedir. Bu kesimin varlı̆ının, Türkiye'de yaşanan yapısal dönüşüm sürecinin ekonomik ve toplumsal sancların azaltıcı yönde rol oynadığı, bazı sorunlan emen bir tampon mekanizma oluşturduğu söylenmelidir.

\section{TARIM IŞ̧̧iLERININ SOSYAL VE HUKUKSAL DURUMLARI ILE ÇALIŞMA KOŞULLARI}

\section{A. Giriş}

Sosyal koruma açısından tarım kesimi dünyanın her yerinde sorunlu olmuş ve koruma bu alana diğer faaliyet kesimlerine göre daha geç girebilmiş ve daha düşük düzeylerde kalmıştır. ${ }^{48}$ Tarımın doğa şartlarına bağımlılığı, tarım işletmelerinin bünyeleri, tarım kesiminde çalı̧̧anların örgütlenme düzeyinin düşüklüğü ve yeterince hakların arayamamaları vb. faktörler bu oluşum üzerinde etkili olmuştur. Türkiye'nin durumu da bir istisna değildir ve dönem itibariyle tarım iş̧̧ileri her türlü sosyal ve hukuki korumadan mahrumdurlar. 1936 tarihli ve 3008 sayılı İs Kanunu, tarım kesimini kapsam dışında bıraktığı için; tarım iş̧̧ilerinin yasanın özellikle bireysel iş ilişkileri alanındaki koruyucu hükümlerinden yararlanması olanaksız hale gelmişti. Kuşkusuz, tarım kesiminin dışarıda bırakılmasının nedenleri vardı. Tarım kesimindeki işgücü, çok değişik statüler içcrisinde bulunmaktaydı ve bunlar içerisinde ücretlilerin ağırlığı çok fazla değildi. Ayrıca, bu ücretli kesimin İs Kanunu kapsamına alınmasına ilişkin teknik güçlükler de bulunmaktaydı. Tarımdaki işgücünün; iş̧̧, işveren, ortakçı, kirac, yarıcı vb. çok değişik biçimlerde çalışıyor olması ve kimi zaman bunların iç içe geçmiş olması nedeniyle, işgücü içerisinde yer alan iş̧̧ilerin net bir biçimde saptanması bile olanaklı değildi. Bunun yanunda, tarım kesiminde mevsimlik çalışmanın şok yaygın olması, işgücünün coğrafi dağınıklığı da; sorun yaratan faktörler arasındaydı. Tüm bu faktörler, yasanın kapsamına girecek olanları saptama yanında, denetim zorluğu da yaratmaktaydı. ${ }^{49} \mathrm{Bu}$ faktörler, genel çizgileriyle diğer ülkelerdekine benzemekteydi. Ancak, tüm güçlüklere karşın, tarım işçilerinin İş Kanunu kapsamı dışında tutulması, bunların her türlü sosyal korumadan mahrum olmaları sonucunu doğurdu. Hukuksal bir düzenlemeye tabi tutulmayan tarım

47 Bu özellikler konusunda, bakınz, (TEKELl, 1982a: 158-159).

$48 \mathrm{Bu}$ gecikmeye etkide bulunan faktörlere ilişkin değerlendirmeler için, bakınz, (NALBANDOC̆LU, 1948: 18-19; AKSOY, 1969: 12-21).

49 Iş Kanunu'nun tarım kesimine ilişkin sınırlamasınn dönemin Türkiye koşullan çerçevesinde geniş bir değerlendirmesi için, bakınız, (SAYMEN, 1954: 227-228). 
kesimindeki iş̧̧i-işveren ilişkileri; bölgeden bölgeye de değişiklik gösteren ve çok defa uyulmayan yerel örf, adet ve geleneklere dayanmaktaydı (ÇALGÜNER, 1943: 111). Daha Iş Kanunu hazırlanurken, tarım kesimi için de benzeri bir kanunun çıarılması konusu tarı̧̧ma alan bulmuş, bu konuda bazı ön hazırlıklar da yapilmışı (ÇALGÜNER, 1943: 112). Ancak daha sonra bu konuda olumlu gelişmeler olmamıştır.

1950'li yıllarda Iş Kanunu'nda çeşitli değişiklikler yapılırken, tarım kesimi için sadece "çiftçilik" ifadesi yerine "tarım işleri" ifadesi geçirilerek sınurl bir kapsam genişlemesi yaratıldı. Ama, gene yasa kapsamı dışında kalan iki kesim için Basın Iş Kanunu ile Deniz Iş Kanunu çıkarlırken, tarım kesimi için benzeri bir düzenlemeye gidilmedi. Oysa, tarım iş̧̧lerinin, özellikle geçici tarım iş̧̧ilerinin çalışma koşulları, diğer kesimlerdekinden çok daha kötüydü. Mevsimlik iş̧̧ilerin köylerinden yola çıkmalarıyla başlayan süreç; olumsuz ulaşım, sağlık, barınma ve beslenme koşullarını da içermekteydi. ${ }^{50}$ İşciler işverenin yan sıra, elci, çavuş, dayıbaşı vb. sözcüklerle anılan aracların egemenliği altındaydı (URAN, 1939: 19-25; NALBANDOĞLU, 1948: 24; AKSOY, 1971: 116). ${ }^{51}$ Sayıları yüz binleri bulan mevsimlik iş̧̧ilerin çalışma süreleri günde ortalama 12-14 saat arasında değişiyordu ve buna rağmen ücret düzeyleri de diğer kesimlerdekinden çok daha düşüktü. Tarım işçileri içerisinde süreklilik niteliği taşıyanların ağırlıklı olmadığı; geçici, mevsimlik iş̧iliğin yoğun olduğu düşünülecek olursa, örneğin ylllık ücret gelirleri itibariyle bir değerlendirme yapıldığında farklılık daha da çarpııı hale gelir.

Bu kesime yönelik olarak gerçekleşen belki de tek koruyucu uygulama, 1951 yılında başlayan asgari ücret saptamalarıdır. Bu çerçevede, 8 Ocak 1951 tarihinde yürürlüğe giren Asgari Ücretlerin Tesbitine Müteallik Yönetmelik ile

$50 \mathrm{Bu}$ koşullar hakkında bilgi, değişik kaynaklarda bulunabilir. Örneğin, bakınız, (ÇALGÜNER, 1943: 47 vd.; TARUS, 1946: passim; NALBANDOĞLU, 1948: passim). 1940'h ve 1950'li yıllarda tarım iş̧̧ilerinin yaşama ve çalışma koşullan birçok edebi esere de konu olmuştur. Bunlar arasında Çukurova'daki geçici tarım iş̧̧lerinin sorunların anlatan Orhan Kemal'in eserleri özellikle önemlidir ve bu döneme tanıklık etmektedir. Yazann bu tür eserlerinin en önemlisi de, kanımızca, Bereketli Topraklar Üzerinde adlı romandır. Romandan, tarım iş̧̧ilerinin yaşama koşullarıyla ilgili bir bölümü aktarmak istiyoruz: "Pek pek birkaç hafta sonra "Urumdan Şamdan" çekilip çekilip gelen ırgat kafilelerinin akını başlar. Binlerce kadın, erkek, çoluk çocuk, genç, yaşı, paramparça üstbaşlarıyla pis pis kokarak, Ötegeçe'deki mezarlığa yığılırlar. Kıçı çıplak çocuklar mezar taşlarına inip biner, tevekkül içindeki kadınlar, Taşköprü'nün bu geçesindeki urgat pazarından iş ve ekmeğin sevinciyle gelecek erkeklerini beklerler. Kul acımaz bunlara, Allah acımaz. Allahın unuttuğu insanlardır bunlar! Peygamberler kitaplar dolusu sabır, tevekkül, kanaat getirmişlerdir bunlara. Hişbir işe yaramıyan, hiçbir işe yaramıyacak olan sabır, tevekkül, kanaat!" Bakınız, (KEMAL, 1964: 184).

51 Elcilerin faaliyetleri konusunda geniş bilgi için, bakınız, Tarus, 1946, passim. Bu müessesenin Is ve Iş̧̧ Bulma Kurumu kurulduktan sonra da varlığını sürdürmesi, yüzyılık bir uygulama olmasınun yanı sıra, iş̧̧i ve işveren açısından sahip olduğu bazı avantajlara bağlanmaktadır. Bakınz, (TODAlE, 1958: 20). 
belirli illerde ve belirli tarımsal işlerde asgari ücret belirlemeleri yapıldı. Ancak, tarım kesimine yönelik asgari ücret uygulamaları, hem il, hem de işkolu itibariyle sınırlı kaldı. Belirlenen ücret düzeyleri de, zaten diğer kesimlerden düşük olan ortalama tarımsal ücretlerin epeyce altundaydı. Uygulamada ise değişik nedenlerle belirlenen bu ücret düzeylerine dahi uyulmadığı gözlendi. Konuya ilişkin kapsamlı değerlendirme ve karşlaş̧urmalar, az aşağıda yapulacaktr.

Tarım işçilerinin temel sorunlarından biri ise sosyal güvenliğe ilişkindi. 1945 yılında Işç Sigortaları Kurumu'nun ve tedrici bir biçimde değişik sigorta kollanın kurulmasına karşın, Sosyal Sigortalar Kurumu'nu kuran 1964 tarihli 506 Sosyal Sigortalar Kanunu öncesinde çkarılan bütün bu yasalar, sigorta kapsamını 1936 tarihli ve 3008 saylı Is Kanunu ile sınurlandırmıştı. İ̧ Kanunu tarım kesimini kapsam dışı bıraktığı için; zaten her türlü güvenceden uzak ve zor koşullarda çalışan tarım iş̧̧ileri, sosyal güvenlik şemsiyesi dışında da kalmışlardı. 506 sayılı kanun ise tarım sanatlarına ait işler hariç kalmak üzere, tarım işlerinde çalışanlanı sigorta kapsamı dışında bırakmıştı. Kuşkusuz, tarım kesiminin Iş Kanunu gibi, sosyal güvenlik kapsamı dışında tutulmasının da benzer nedenleri bulunmaktaydı. Gelir düzeyinin düşüklüğü yanında süreksizliği, işçi - işveren - ortakģ gibi kategorilerin çoğu zaman iç içe geçmiş olması bunlar arasındadır. ${ }^{52}$ Ama diğer taraftan, tam da bu nedenler, tarım işçilerini sosyal güvenliğe en çok ihtiyaç duyan kesim yapmaktaydı. Tarım işçileri, ancak 1977 yılında 506 sayılı Sosyal Sigortalar Kanunu'nda değişiklik yapan 2100 sayılı kanunla sosyal sigorta kapsamina alındılar. ${ }^{53}$

Tarım işçilerinin durumları sendikal örgütlenme açısından da değerlendirilmelidir. 1947 tarihli ve 5018 sayıl yasa, açık bir biçimde ifade edilmemesine karşılık, tarım iş̧̧ilerine de sendika hakkını vermekteydi (ERKUL, 1967: 98). Nitekim, 5018 sayli yasanın uygulanma şeklini gösteren Talimatnamenin 8. maddesinin 3. flkrasında "Gerek iş̧̧i ve gerekse işveren sendikaları, henüz Iş Kanunu hükümlerine tâbi bulunmayan kara işyerlerindeki iş̧̧ler veya işverenlerle, deniz, tarım veya hava iş̧̧ileri veya işverenleri tarafından da kurulabilir." denilmekteydi. ${ }^{54}$ Ancak, çalışmamızda tarım iş̧̧ilerine ilişkin olarak değerlendirdiğimiz koşullar, dönem içerisinde tarım iş̧̧lerinin sendikal örgütlenmelerini de olumsuz yönde etkilemiştir. 1947 yllından 1951 yılına kadar tarım işkolunda sendikaya rastlanmamıştır (GÜNGÖR, 1998: 151). Daha sonraki yllarda kurulun az sayıda sendikanın büyük bölümü ise ya faaliyet göstermemiş ya da münfesih olmuşlardır.

52 Bu nedenler konusunda, bakınız, (BÜLBÜL, 1982: 21).

53 Kabul tarihi:11.8.1977, Resmi Gazete:24.8.1977, Say:16037. Konuya ilişkin gelişmeler için, bakınız, (BÜLBÜL, 1982: 20-21).

54 Talimatname'nin metni, (SUNAR, 1955: 361-370)'de bulunmaktadır. 
Kuruldukları saptanabilen 11 sendikanın 9'unun ise Çukurova Bölgesi'nde olduğu görülmektedir. ${ }^{55} 1963$ tarihi itibariyle dahi, üye sayılan ancak 5 080'e ulaşan 10 sendika mevcut bulunuyordu ve bunların çalışma koşullarının belirlenmesi üzerinde herhangi bir etkinlikleri yoktu (KAZGAN, 1963: 54). 1963 sonrasınun yeni çalışma düzeni içerisinde, tarım kesimindeki sendikalar artış gösterecektir.

Benzeri değerlendirmelerin, tarım kesiminde iş̧̧ilik dışında ortakçı ve kiracı olarak çalışanlar açısından da yapılması icap eder. Çünkü bu kategorilerde çalışanların durumu, farklı bir statü içerisinde yer alıyor gibi gözükmelerine karşın, iş̧̧ilere benzemektedir. Özellikle arazi sahibi ile "ortaklıklarına" ağırıklı olarak işgüçlerini koyan ya da işgüçleri dışında hiç bir şey koymayan ortakçılar, tümüyle birer tarım iş̧̧isi konumundadırlar. Arazi sahibi ile 1926 tarihli Borçlar Kanunu'nun hâsılat kirası çerçevesinde ve irade serbestisi içerisinde ilişkide bulunan, ancak ekonomik ve toplumsal olarak eşit bir ilişki kurma olanağına sahip olmayan bu kesimin çalışma koşulları da zor ve güvenceden uzaktır. ${ }^{56}$

\section{B. Tarımsal Ücretlerdeki Gelişmeler}

1950-1960 döneminde tarım kesimindeki iş̧̧i ücretlerinde meydana gelen gelişmeleri, hem kendi içinde gösterdiği değişimler, hem de diğer kesimlerdeki ücretlerle karşılaştırmalı olarak değerlendirmek yararlı olacaktır. Aşağıdaki tabloda, 1950-1963 döneminde nominal ve gerçek ücretlerde ortaya çkan değişmeler tarım ve imalat sanayii itibariyle verilmektedir. Bu tablodaki veriler, sayım niteliğinde kaynaklardan derlenmiş olmayıp, değiş̧ik verilere dayanılarak. yapılan bir tahmin olma niteliğini taşımaktadır.

55 Işkolunda kurulu sendikaların bir listesi için, bakınz, (GÜNGÖR, 1998: 152). 1947-1955 döneminde kurulan sendikaların bir listesi için, bakınz, (SÜLKER, 1955: 85-97).

56 Bu kesimin çalışma koşullarının değerlendirilmesi konusunda, bakını,, (AKSOY, 1971: 119-121). 
Tablo V: 1950-1963 Döneminde Nominal ve Gerçek Ücretlerdeki Gelişmeler (TL / Ay)

\begin{tabular}{|c|c|c|c|c|c|c|c|}
\hline & Imalat sanayii & \multicolumn{4}{l|}{ Tarım } & \\
\hline Yillar & $\begin{array}{c}\text { Nominal } \\
\text { ücretler }\end{array}$ & $\begin{array}{c}\text { Gerçek } \\
\text { ücretler } \\
\text { (1968 yllı } \\
\text { fiyatlariyle) }\end{array}$ & $\begin{array}{c}\text { Gerçek } \\
\text { ücret } \\
\text { indeksi, } \\
1950=100\end{array}$ & $\begin{array}{c}\text { Nominal } \\
\text { ücretler }\end{array}$ & $\begin{array}{c}\text { Gerçek } \\
\text { ucretler } \\
\text { (1968 yılı } \\
\text { fiyatlariyle) }\end{array}$ & $\begin{array}{c}\text { Gerçek } \\
\text { ucret } \\
\text { indeksi, } \\
1950=100\end{array}$ & $\begin{array}{c}\text { Tüketici } \\
\text { fiyat } \\
\text { indeksi } \\
1968=100\end{array}$ \\
\hline 1950 & 121 & 436 & 100 & 77 & 277 & 100 & 27.78 \\
\hline 1951 & 131 & 471 & 108 & 97 & 349 & 126 & 27.82 \\
\hline 1952 & 148 & 506 & 116 & 109 & 364 & 131 & 29.23 \\
\hline 1953 & 165 & 544 & 125 & 126 & 415 & 150 & 30.33 \\
\hline 1954 & 182 & 548 & 126 & 109 & 328 & 118 & 33.21 \\
\hline 1955 & 202 & 542 & 124 & 130 & 349 & 126 & 37.26 \\
\hline 1956 & 239 & 583 & 134 & 150 & 366 & 132 & 40.96 \\
\hline 1957 & 285 & 622 & 143 & 211 & 461 & 166 & 45.82 \\
\hline 1958 & 336 & 633 & 145 & 249 & 469 & 169 & 53.06 \\
\hline 1959 & 430 & 652 & 150 & 277 & 420 & 152 & 65.99 \\
\hline 1960 & 478 & 688 & 158 & 298 & 429 & 155 & 69.43 \\
\hline 1961 & 493 & 699 & 160 & 297 & 421 & 152 & 70.50 \\
\hline 1962 & 534 & 733 & 168 & 351 & 482 & 174 & 72.88 \\
\hline 1963 & 578 & 735 & 169 & 405 & 515 & 186 & 78.66 \\
\hline
\end{tabular}

Kaynak: BULUTAY (1995: 301-302, 306, Tablo 9.G, Tablo 9.J)'deki verilerden düzenlenmiş ve hesaplanmıştır.

Tablodaki verilerden imalat sanayiinde gerçek ücretlerin 1955 yılı dışında sürekli artış eğilimi gösterdiği, 1950-1963 yılları arasındaki artı̧ın ise \% 69 oranında olduğu görülmektedir. Buna karşllı tarım kesiminde ücretler ayn dönem içinde \% 86 oranında artı̧ göstermektedir. Tanm kesimi ücretlerinin çok düşük olduğu 1950 yılı yerine 1951 yılı temel alınırsa, 1963'e kadar olan reel ücret artı̧ oran sadece \% 47.5 olmaktadır. Tarım kesiminde ücretlerin inişli çıkışı bir seyir izlediği de görülmektedir. Bunun, tabloda yer alan verilerin hesaplanma yöntemleri yanunda, tarım kesiminde üretim koşullarıyla birlikte ücretlerin de konjonktürden ve üretim miktarı üzerinde etkili olan doğa koşullanndan etkilendiği biçiminde yorumlanması uygun olacaktr. 
Imalat sanayii ile tanm kesimi arasındaki ücret farkllığı zaman içerisinde varlığını korumakta; yıldan yıla küçük değişikliklerle, imalat sanayiinde ücretler tarım kesimindekinden yaklaşık \% 50 oranında daha yüksek bulunmaktadır. Tarım iş̧̧ileri içerisinde süreklilik niteliği taşıyanların ağırlıklı olmadığı; geçici, mevsimlik iş̧̧iliğin yoğun olduğu düşünülecek olursa, örneğin ylllık ücret gelirleri itibariyle bir değerlendirme yapıldığında farklılık daha da çarpıc hale gelecektir.

Tarım kesimindeki ücretlere ilişkin olarak, cinsiyete dayalı ücret farklılıklarını da değerlendirmek icap eder. Hemen her ülkede ve her dönemde gözlenen ve bu nedenle evrensel olarak nitelenebilecek olan eğilim, erkek işçi ücretlerinin kadın iş̧̧i ücretlerinden daha yüksek olmasıdır. Bir başka çalı̧̧mamızda, dönem itibariyle Türkiye'de tarım dışı kesimlerdeki cinsiyete dayalı ücret farkhlıkların kapsamlı bir biçimde değerlendirmiştik. ${ }^{57}$ Bu ücret farklılıkları, başta işgücünün eğitimi ve niteliği olmak üzere çok sayıda faktör tarafından belirlenmekte ve toplumsal değer yargılarınn izlerini de taşımaktaydı. Tarım kesimi için benzeri bir değerlendirmede kullanılacak veriler sunırlı ve eski olmakla birlikte, araştırmalar, bu kesimde cinsiyete dayalı ücret farklılıkları olduğunu ortaya koymaktadır. Çalgüner'in 1939-1940 için vermis olduğu rakamlar, Türkiye geneli itibariyle erkek iş̧̧ ücretlerinin 60-100 kuruş, kadın işçi ücretlerinin 30-50 kuruş, çocuk iş̧̧ ücretlerinin ise 20-35 kuruş dolaylarında olduğunu ortaya koymaktadır. Ancak yazarın değerlendirmeleri, bu farklılıkların büyük ölçüde iş veriminden ve yapılan işin çeşidinden kaynaklandığın ortaya koymaktadır (ÇALGÜNER, 1943: 65). Cinsiyete dayalı ücret farklılıklarında, bölgeden bölgeye değişen gelenekler de rol oynamaktadır. Örneğin, Çukurova Bölgesi'nde işçi ücretleri cinsiyete göre farkllaşmazken, Ege ve diğer bazı bölgelerde farklılaşabilmektedir (ÇALGÜNER, 1943: 71).

\section{Tarım Kesimindeki Asgari Ücreł Uygulamaları}

1950'li yıllarda tarım iş̧̧ilerine yönelik olarak gerçekleşen belki de tek koruyucu uygulama, asgari ücret saptamalan idi. Dönem itibariyle Türkiye henüz Uluslararası Çalışma Örgütü'nün 1951 tarihli ve 99 sayılı tarım kesimine ilişkin Asgari Ücret Saptama Yöntemleri Sözleşmesi'ni onaylamamıştı. ${ }^{58}$ Buna karşllık, Asgari Ücretlerin Tesbitine Müteallik Yönetmelik uyarınca Türkiye'de ilk asgari ücret belirlemesi tarım kesiminde yapıldı. Uygulama, 1951 yllında pamuk toplama ve çapa işlerinde başlamıs; bunu 1958 yılında çeltik; gene ayn yılda üzüm, incir, zeytin, meyankökü, tütün; 1960 yllında pancar, tütün, biber yetiştirilmesi; 1961 yllında bağ, bahçe, sebze işkolu izlemişti (KUTAL, 1969: 208). 
1963 yllından itibaren ise tarım tek bir işkolu olarak kabul edilerek asgari ücret belirlenmesine gidilmiştir. Ancak, 1950'li ylllarda tarım kesimine yönelik asgari ücret uygulamaları, alanlar kadar mekan olarak da sınurlı kalmıştur. Örneğin 1951-1963 döneminde pamuk çapa işleri için yapılan saptama, sadece üç ille; Adana, Hatay, Içel'le sınurlı kalmış, özellikle Ege Bölgesi'ndeki pamuk işçileri için benzeri bir uygulamaya gidilmemiştir. Aşağıdaki tabloda asgari ücretler konusundaki değerlendirmelerimize malzeme teşkil etmek üzere; pamuk çapa işi için saptanan asgari ücret ortalamalarını, tarım kesiminde Türkiye ortalaması olarak tahmin edilen ücretlerle karşılaşturnyoruz. Ancak, tarım kesimi için saptanan ücretlerde yatacak ve yiyecek işverene ait olduğu için, bu tablodaki karşlaştırmadan kesin sonuçlar çkarmak güçtür.

Tablo VI: Pamuk Çapa Iş̧i Için Saptanan Asgari Ücretlerin Tarm Kesimi Ortalama Ücretleriyle Karşılaş̧tırlması (1951-1963)

\begin{tabular}{|c|c|c|c|c|c|}
\hline Yillar & $\begin{array}{c}\text { Ortalama } \\
\text { tarımsal } \\
\text { asgari ücret } \\
\text { (Aylık, lira)* }\end{array}$ & $\begin{array}{c}\text { Tarımsal } \\
\text { kesimde } \\
\text { ortalama ücret } \\
\text { (Aylık, lira) }\end{array}$ & $\begin{array}{c}\text { Fiyat indeksi } \\
\text { (İstanbul } \\
\text { geçinme } \\
1951=100\end{array}$ & $\begin{array}{c}\text { Ortalama reel } \\
\text { tarımsal asgari } \\
\text { ücret (1951 yılı } \\
\text { fiyatlarıla }\end{array}$ & $\begin{array}{l}\text { Ortalama tarımsal } \\
\text { ücretin yüzdesi } \\
\text { olarak asgari } \\
\text { ücret }\end{array}$ \\
\hline 1951 & 62 & 97 & 100 & 62.00 & 63.92 \\
\hline 1952 & 66 & 109 & 105.92 & 62.31 & 60.55 \\
\hline 1956 & 83 & 150 & 149.01 & 55.70 & 55.33 \\
\hline 1959 & 117 & 277 & 233.24 & 50.16 & 42.24 \\
\hline 1961 & 152 & 297 & 255.49 & 59.49 & 51.18 \\
\hline 1963 & 189 & 405 & 283.10 & 66.76 & 46.66 \\
\hline
\end{tabular}

Kaynak: KUTAL (1969: 209. Tablo 167), DIE (1973: 367), BULUTAY (1995: 301-302, Tablo 9.G)'deki bilgilerden hesaplanmuştır.

Karşlaştırmalar, tarım kesimindeki asgari ücretlerin, sanayideki asgari ücretlerden daha düşük olduğunu, ancak farklılığın çol büyük olmadığını ortaya koymaktadır. Asgari ücretler günlük olarak mensucat sanayiinde 1959 'da 655, 1963 'te 920 kuruş; tütün sanayiinde ise aynı yıllar için 583 ve 890 kuruştu (KUTAL, 1969: 200, 205; Tablo 12, 15). Tarm kesimindeki asgari ücret mensucat

* Verilen günlük asgari ücret, karşılaştırma yapabilmek amacıyla, haftalık 5.5 gün hesabıyla ve dört hafta üzerinden aylik ücrete dönüştürülmüştür. 
sanayiindekinin 1959 'da \% 81'i, 1963'te ise \% 93'ü düzeyindedir. Konu, asgari ücretler değil de, sektörlerdeki ortalama ücretler itibariyle düşünüldüğünde, iki sektör arasındaki ücret farklılıkları daha yüksek düzeydedir. Bu nedenle, asgari ücret saptamalarında tarımla sanayi arasındaki farkın daralmıs olduğu ifade edilebilir. Buna, tarım kesiminde yatacak ve yiyeceğin işverene ait olması da eklendiğinde, belirlenen asgari ücret düzeylerine uyulmuş olduğu varsayımıyla durum tarım kesimi lehine bile dönebilecektir. Ancak, böyle bir karşılaştırmanın anlamlı olması için, iki sektördeki çalışma sürelerinin eşit ya da birbirine yakın olması gerekir. Oysa, tarım kesimindeki çalı̧̧ma süreleri, İ̧ Kanunu kapsamında çalş̧anlar açısından geçerli olan haftalık 48 saatlik sürenin çok üzerindedir. Örneğin tarım işçiliğinin yoğun olduğu Çukurova bölgesinde çalışma süresi haftada 5.5 gün üzerinden; günde brüt olarak 14 saat, dinlenmeler çıtığında ise net olarak 12 saattir (IIBK, 1959: 76). ${ }^{59}$

Buna karşılık, tarımsal asgari ücretlerin aynı kesimdeki ortalama ücretlerden çok daha düşük olduğu, oranın \% 50'ler civarında kaldığı görülmektedir. Tarımsal asgari ücretlerin satın alma gücü itibariyle bir değerlendirme yapıldığında ise 1950'li yıllarda bu açıdan düşüşler yaşandığı, 1951 yllındaki düzeyin ancak 1963 yllında aşılabildiği görülmektedir.

Kuşkusuz bu ücret düzeylerinin, uygulama açısından da değerlendirilmesi icap eder. Inceleme dönemimiz itibariyle asgari ücret uygulaması, gerck iller, gerekse işkolları itibariyle tarım iş̧̧lerinin çok küçük bir bölümünü kapsadığı gibi, belirleme her yllı kapsayacak biçimde düzenli olarak da gerçekleştirilmemiştir. Belirlenen bu ücret düzeylerine uyulmaması da, önemli sorunlardan biri olmuş; hatta saptanan asgari ücretin uygulamada pamuk iş̧̧lerine ödenen ücretin en üst sınırı olarak kabul edildiği gözlenmiştir (AKKAYA / ALTIOK, 1996: 256).60 Çalışma Bakanı Samet Ağaoğlu'nun 1953 yılında Çukurova'da bizzat yerinde yaptığı gözlemlerden sonra İş ve İş̧i Bulma Kurumu'na gönderdiği tamimde, bu sorunların varlığı en yetkili ağız tarafından ifade edilmektedir (ÇVD, 1953: 47-48):

"Adana ve İçel'de vaki tetkiklerim neticesinde ziraat iş̧̧ileri asgarî ücretleri tesbit sistemi ile bu ücretleri tesbit eden komisyonların çalışma tarzlarında bazı değişiklikler yapılması lüzumuna kani oldum. Filhakika, bir taraftan asgarî ücret namı altında hakikatte sabit ücretler tesbit edilmekte ve bu

59 Bir başka kaynakta, dönem itibariyle pamuk çapalama işinde çalışan iş̧̧ilerin ortalama gündelik çalışma süresinin 16 saat dolaylarında olduğu ifade edilmektedir. Bakınız, (AKKAYA / ALTIOK, 1996: 255).

60 Iş ve Iş̧̧i Bulma Kurumunun 1958 yalında Akdeniz Bölgesi'nde yaptığı işgücü anketi sonuçlarında durum açıklıkla ifade edilmektedir: "Iş̧̧i gündeliklerinin tesbitinde her ne kadar asgari ücret komisyonlan kararları nazara alınmakta ise de, bunda arz ve talep kanunu hükümleri yürümektedir. Umumiyetle tanınmış bir işverenin vereceği yevmiye esas tutulmaktadır." Bakınız, (llBK, 1959: 82). 
sebeple mevsim ve çalışma sahasının değişen şartlarının husule getirdiği yeni arz ve taleo dalgalanmaları dikkat nazarına alınmadığından ya fiilî ücretler, tesbit edilmiş ücretler altunda tecelli etmekte veyahut da ayn iktisadî şartları haiz Çukurova bölgesinin üç vilâyetinde ayn zamanda kısmî işçi bollukları veya işçi azlıkları meydana gelmektedir. Bazan da her iki hal birden vaki olmaktadır. Komisyonların bugünkü terekküp tarzları da işin iki tarafını teşkil eden iş̧i ve işvereni memnun etmekten uzaktır. Zira, bu komisyonlarda fiilen ekseriyette olanları işle ilgisi bulunmayanlar teşkil etmektedir..."

1960'l y yllarda dahi, tarım kesiminde belirlenen asgari ücret düzeylerine riayet edilmediği durumlar gözlenmiş, bunda, sektördeki işçilerin örgütsüz oldukları için bir baskı yapacak durumda olmamaları ve asgari ücretlerin işverenlerce uygulanmamasına karşı etkin müeyyidelerin bulunmayışı rol oynamıştır (TALAS / DILIK / IŞIKLI, 1965: 5). ${ }^{61}$

\section{Ç. Tarım İ̧̧̧ilerinin Çalışma Süreleri}

Türkiye'de 1936 tarihli İş Kanunu, kapsamına giren iş̧iler açısından çalışma süresini haftada 48 saat olarak belirlemişti. Bunun, dönem itibariyle yeterli denetim olanaklan olmasa da, önemli bir koruma sağladığı söylenebilir. Buna karşılık kanunun kapsamı dışında kalan en önemli iktisadi faaliyet alanı olan tarım kesimi açısından böyle bir belirleme mevcut değildi. Bu çerçevede tarım kesiminde çalı̧̧ma süreleri, yüzyllardır süre gelen örf ve adetlerle belirlenmiştir ve genellikle gün doğumundan gün batımına kadar olan süredir (ÇALGÜNER, 1943: 40-41; ERKUL, 1967: 95).62 Ancak, tüm tarım kesimini kapsayan mutlak bir çalş̧ma süresi telaffuz etmek olanaklı değildir. Çalışma süreleri, bölgeden bölgeye değiştiği gibi, yctiştirilen ürünlere göre de farklıllı göstermektedir.

Tahıl üretiminde çalışan iş̧̧ilerin yllın $1-1.5$ ayında ve günde 13 - 14 saate ulaşan sürelerle çalıştığı söylenebilir (NALBANDOĞLU, 1948: 21). Buna karşıllık pamuk ziraatinde çalş̧an işçler yılda $3-4$ ay ve günde 13 - 14 saat çalışmaktadırlar (NALBANDOĞLU, 1948: 22).63 Tütüncülük alanında

61 Benzeri sorunlar ve değerlendirmeler için, bakını, (KUTAL, 1969: 212).

62 Osmanlı Imparatorluğu'nda 1869-1876 yılları arasında çıkarılan Mecelle, çalı̧sma sürelerini "Gün doğumundan gün batımına kadar olan süre" olarak belirlemişti. Mecelle'nin bu düzenlemesi konusunda, bakınız, (MAKAL, 1997: 201-202). Aradan geçen uzun yllara karşın, tarım işçlerinin durumlarının Mecelle'nin düzenlemesinden farklılaşmadığı görülmektedir.

63 Iş ve Iş̧̧i Bulma Kurumu'nun 1950'li yılların sonunda gerçekleştirdiği işgücü anketleri, ağırlıklı olarak pamukta çalışan tarım iş̧̧lerinin ortalama yıllık çalışma sürelerini de ortaya koymaktadır. Akdeniz Bölgesinde gerçekleştirilen ankete göre işçilerin dişarıda kalma süreleri, gidilen bölgeye göre değişmekle birlikte ortalama 117 gün yani dört ay dolayları̣ndadır. Rakam, (11BK, 1959: 28)'deki verilerden hesaplanmıştır. 
çalışanların çalışma süreleri ise daha da uzundur. "Dikme ve çapa esnasında bütün gün 13 - 14 saat olan günlük iş müddeti, kırıp dizme zamanunda 3 aydan fazla bir müddet 18 , hattâ iş yerine gidip gelme de hesaba katılmak suretiyle 20 saate kadar çikar." (NALBANDOĞLU, 1948: 26). ${ }^{64}$ Gündelik çalı̧̧ma süreleri 20 saate ulaşan tütün iş̧̧ilerinin 40 yaşından sonra çalışma kapasitelerini kaybettikleri ifade edilmektedir (NALBANDOĞLU, 1948: 29; AKSOY, 1969: 44). Ücretli tütün işçiliğinin diğer alanlardan önemli bir farklılığ ise genellikle bir aile işi olarak değerlendirilmesidir. Günlük ortalama çalışma süresi 15 - 18 saat arasında değişen ve yaklaşık üç dört ay süren bu işte; kadınlar ve $10-11$ yaşındaki çocuklar da, ailenin diğer fertleriyle birlikte çalışmaktadırlar (YASA, 1960: 51).65

Çalışma süreleri konusunu, günlük çalışma süreleri, günlük dinlenme süreleri ve haftalık tatiller itibariyle değerlendirmek icap eder. Bu konuda da Türkiye'nin değişik bölgelerinde değişik uygulamalar mevcuttur. Is ve Iş̧̧i Bulma Kurumu'nun 1958 Akdeniz Bölgesi araştırması pamuk çapasında fiilen sabah saat 5.00 'te işe başlandığın ve 19.00 'da son verildiğini, günde iki saat yemek ve dinlenme molası verildiğini, net çalışmanun ise 12 saat olduğunu ortaya koymaktadır (İBK, 1959: 76-77). ${ }^{66}$ Buna karşıllı çapa işinde haftada 5.5 gün çalışlıp, bir haftalık yevmiye alınmaktadır (AKSOY, 1969: 92).67 Pamuk toplama işinde iş̧̧iler topladıkları kilo başına ücret aldıklan için, "haftalık tatillerini kendiliklerinden feda" etmektedirler.

Bı sınırlar, Çukurova Bölgesi'nde geleneksel olarak belirlenmiş olup, diğer bölgelerde bu kadar düzenli ve yeknesak kurallar bulunmamaktadır ve çalışma süreleri daha da uzun ve düzensiz olabilmektedir (ERKUL, 1967: 95).68 Ayrıca, tarım işçilerinin bu uzun çalışma sürelerinin; olumsuz barınma, beslenme, sağlık sorunları ile birlikte gittiğini de gözden rak tutmamak icap eder. Tarım kesimindeki bu uzun çalışma sürelerine tabi olan işçi sayıları düşünüldüğünde, durumun vahameti ortaya çımaktadır. Dönem itibariyle sadece Iş ve Iş̧̧i Bulma Kurumu'nun tarımsal işlere yerleştirdiği kişi sayısı 1953 'te 100291,1954 'te 204813,1960 'ta ise 368735 'tir (BUMH, 1955: 8; Erkul, 1967: 84). Toplam işçi sayısı ise bir milyonun üzerindedir.

64 Çalışma süreleri konusunda ayrıca bakınız, (KAZGAN, 1963: 55).

65 Yasa'un gözlemleri 1950 ylında Bergama'nın Sindel köyündeki koşullan yansıtmaktadır.

66 Iş̧iler geleneksel olarak sabah ezanında işe başladıklarından, bazı işverenlerin imamla anlaşarak ezanı zamanından önce okutturduklan da nakledilmektedir. Bakını, (IlBK, 1959: 76).

67 Bu uygulama 1833-1840 yılları arasında Adana'yı yöneten Ibrahim Paşa'nın hazırladı̆̆ı ve Türkiye'de 1950'li yıllara kadar uygulanan nizamname uyarınca yapılmaktaydı. Nizamnameyle 5.5 gün çalışan iş̧̧ye 7 günlük ücret veriliyor, günlük dinlenme süreleri artırllyyor ve beslenme $\mathrm{vb}$. sorunlar üzerinde düzenlemeler yapiliyordu. Konuya ilişkin olarak, bakınız, (MAKAL, 1997: 289).

68 Erkul, bu koşullar altında çalı̧ma süreleri açısından Çukurova bölgesi ziraat işçilerini "en şanslı durumda bulunan ziraat iş̧ileri" olarak nitelemektedir. Bakınız, (ERKUL, 1967: 91). 


\section{SONUÇ}

Ikinci Dünya Savaşı sonrası dönemde Türkiye'de önemli bir dönüşüm yaşanmaktadır. Aslında bu dönüşüm bir bütündür ve parçalarn birbirlerine diyalektik biçimde bağlıdır. Bu bütünün önemli ögelerinden biri ise tarım kesimidir. Kuşkusuz tarım kesimindeki dönüşüm de, kendi içinde olduğu kadar; tarım dışı kesimlerde yaşanan gelişmeler tarafından belirlenmektedir. Soruna tarım kesiminin kendi içinden bakıldığında, veriler, bu kesim açısından son derecede önemli olan arazi mülkiyetinde dönem içerisinde ciddi değişmelerin ortaya çkmadığın göstermektedir. Küçük toprak mülkiyeti, dönemin başında da, sonunda da Türk tarıminda egemen olmaya devam etmektedir. Ciddi bir değişikliğin gözlenmediği arazi mülkiyetiyle bağlantılandırılması zor olan değişimin altında, tarım kesiminde yaşanan teknolojik değişme, bu kesime sağlanan kredi vb. olanaklar ile tarım kesiminin iç ve dış piyasalara açılması yatmaktadır. Bu gelişmeler ise tarım kesimi kadar, sanayi ve hizmetler kesimi açısından da önemli sonuçlar doğuracaktt.

Bu değişimlerin öncesinde de, Türk tarımında topraksız köylüler ile tarımsal aile biriminin geçimini sağlamaya yetmeyecek ölçüde küçük araziye sahip olan köylülerden oluşan geniş bir kesim bulunmaktaydı. Bu kesim, tarım ve tarım dışı faaliyet alanlarına yönelip, yılın belirli dönemlerinde geçici iş̧̧ilik yaparak geçimini sağlamaya çabalıyordu. 1950'li ylllarda yaşanan değişimler, arazi mülkiyetinde ciddi değişimler olmamasına karşın, arazi kullanumında ve bunun sonucunda tarım kesiminin insangücü ihtiyacında değişiklikler yarattı. Değişmeler; tarım kesiminin insan gücü ihtiyacın azaltarak; topraktan göreli olarak kopmuş, özgürleşmiş bir işgücü tabakası doğurma yönünde etkiler yapt. Tüm bu gelişmeler, mevsimlik işlere yönelen kişilerin sayısı artırdığı gibi, yöneliş zamanla sürekli bir hal aldı ve kentlere göçe dönüştü.

Tarım kesimindeki gelişmelerin kentsel kesim ve buralarda gelişen sanayi ve hizmetler üzerinde de ciddi etkileri oldu. Yeni gelişen kesimler, insan gücü intiyacını ağırlıklı olarak tarımsal kaynaklardan sağladılar. Başlangıçta geçici ve niteliksiz olan bu isgücü, giderek süreklilik ve nitelik kazandı. Bu çerçevede, Türkiye'de ücretlilik statüsü içerisinde çalışanların sayısının artması, çalışma ilişkilerinin gelişmesi, hep tarım kesimindeki bu değişiklikler çerçevesinde anlamlandınlabilir. Ancak, veriler, her şeye karşın, 1950-1960 döneminde bu gelişmelerin sınırlı olduğunu göstermektedir. Konuya ilişkin esas gelişmeler 1960 sonrası dönemde yaşanacak; ekilen toprakların sınurlarına ulaşıldığı bir durumda zirai makina ve girdi miktarındaki artışlar, tarım kesiminde işgücü ihtiyacını 1950-1960 dönemine göre ciddi ölçüde ve net biçimde azaltacaktır. 


\section{Kaynakça}

\section{Kitaplar ve Makaleler}

AKKAYA, Yüksel / ALTIOK, Metin (1996), "Cukurova'da Pamuk Işçileri," Türkiye Sendikaculk Ansiklopedisi,Birinci Cill (Istanbul: Kültür Bakanlı̨̆ı ve Tarih Vakfı Yayını): 253-257.

AKSOY, Suat (1969), Tanmda /ş Hukuku (Ankara: Türk Ziraî Ekonom Derneği Yayını).

AKSOY. Suat (1971), Türkiye'de Toprak Meselesi (Istanbul: Gerçek Yayınevi, Ikincl Baskı).

AKTAN, Reşat (1978), Türkiye Iktisadı (Ankara: Ankara Üniversitesi Siyasal Bilgiler Fakültesi Yayını, Üçüncu Baskı).

ARUOBA, Çelik (1982), "Cumhuriyetin Kuruluş Yıllarında Türkiye'nin Tarımsal Yapısı ve Tarıma Yönelik Politikalar," Atatürk Dönemi Ekonomi Politikası ve Türkiye'nin Ekonomik Gelişmesi (Ankara: Ankara Óniversitesi Siyasal Bilgiler Fakültesi Yaysnı): 79-88.

ARUOBA, Celik (1988), "Tarımda Teknolojinin Değişmesinin Gelir Dağılımına Etkısi," Şevket Pamuk, Zafer Toprak (Derleyenler). Türkiye'de Tanmsal Yapular (1923-2000) (Ankara: Yurt Yayınları): 197-207.

BORATAV, Korkut (1980), Tanmsal Yapilar ve Kapilalizn (Ankara: Ankara Öniversitesi Siyasal Bilgiler Fakültesi Yayını).

BULUTAY, Tuncer (1995), Employment, Unemployment and Wages in Turkey (Ankara: International Labour Office - State Institute of Statistics).

BÔLBC̈L, Mehmet (1982). "Tarım Iş̧ileri, Sorunlan ve Çözüm Önerileri," Tanm ve Oman Iş̧̧ilerinin Sorunlarına llişkin Çözüm Onerileri Semineri (Ankara: Milli Prodüktivite Merkezi Yayınları): 13.26 .

ClLLOV, Halûk (1972), Türkiye Ekonomisi (Istanbul: Istanbul Öniversitesi lktisat Fakūltesi Yayını).

CALGÖNER, Cemil (1943), Türkiye’de Ziraat Iş̧ileri (Ankara: Ankara Yüksek Ziraat Enstitüsü Rektörlüğũ Yayını).

ERKUL, Ihsan (1967). Türkiye'de Ziraat/ş̧ileri ve Bunlara liş̧kin Calışma Hukuku (lstanbul: Eskişehir lktisadi ve Ticarî liımler Akademisi Yayınlanı).

FLÖGGE, Wilhelm von (1948-1949), "Orta Anadolu'da Ziraî Ișletme Meseleleri." Istanbul Oniversitesi /ktisat Fakültesi Mecmuası (Cilt: 10. No.1-4, Ekim 1948-Temmuz 1949): 122-165.

GŌNGÖR, Yasemin (1998), "Tarım, Ormancilık, Avcılık ve Balıkçılık Işkolu," Türkiye Sendikacılık Ansiklopedisi, Oçüncü Cilt (lstanbul: Kültür Bakanlığı ve Tarih Vakfı Yayını): 148-153.

KANBOLAT, Yahya (1963), Türkiye Ziraatinde Bünye Değişikliği (Ankara: Ankara Öniversitesi Siyasal Bilgiler Fakültesi Maliye Enstitüsü Yayını).

KARAHASANOĞLU, Taner (1970), Kamu Kesimindeki Tarum /şletmelerinde Ocretle Calışanlar ve Sosyal Güvenliklerinin Sağlanması (Ankara: Devlet Planlama Teşkilâtı Yayını).

KAZGAN, Gülten (1963), "Ziraat Iş̧ilerinin Sendikalaşması," Sosyal Siyaset Konferanslan, Ondördüncū Kitap (Istanbul): 47-66.

KAZGAN. Gülten (1977) "Türk Ekonomisinde 1927-1935 Depresyonu, Kapital Birikimi ve Örgütleşmeler," Atalürk Döneminin Ekonomik ve Toplumsal Tarihiyle lgili Sorunlar Sempozyumu, (Istanbul: Istanbul Yüksek Iktisat ve Ticaret Mektebi Mezunları Derneği Yayını): 231-274.

KAZGAN, Gülten (1983), Tarun ve Gelişme (lstanbul: Der Yayınları, OÇ̧üncü Bası).

KAZGAN, Gülten (1988a), "2000 Yilında Türk Tarım»" Şevket Pamuk, Zafer Toprak (Derleyenler); Türkiye'de Tarumsal Yapilar (1923-2000) (Ankara: Yurt Yayınlan): 257-271. 
Ahmet Makal • Türkiye'de 1950-1965 Döneminde Tarım Kesiminde lşgúcul ve Ücretli Emeð̧e llişkin Gelişmeler • 139

KAZGAN, Gülten (1988b), "lzzettin Önder, Ergün Kip ve Cağlar Keyder'in Tebliğlerine llişkin Yorum," Şevket Pamuk, Zafer Toprak (Derleyenler); Türkiye'de Tanmsal Yapular (1923-2000) (Ankara: Yurt Yayinları): 175-178.

KELEŞ, Ruşen (1978), Türkiye'de Sehirleşme, Konut ve Gecekondu (Istanbul: Gerçek Yayınevl, Ikincl Bask)).

KELEŞ, Ruşen / TÜRKAY, Orhan (1962), Köylü Gäzü lle Türk Köylerinde Iktisadĩ ve Toplumsal Değissme (Ankara: Ankara Ôniversitesi Siyasal Bilgiler Fakültesi Maliye Enstitūsü Yayını).

KEMAL, Orhan (1964), Bereketli Topraklar Ozerinde (lstanbul: Remzi Kitabevi, Ikincl Baskı).

KEPENEK, Yakup (1987), Türkiye Ekonomisi (Ankara: Teorl Yayınları).

KETEN, Mustafa (1971). Tanm Işletmelerinin Yapısı (Ankara: Devlet Planlama Teşkilâtı Yayını).

KIRAY, Mübeccel (1972), "Gecekondu - Az Gelişmļ Olikelerde Topraktan Kopma ve Kentle Bütünleşememe," Ankara Oniversitesi Siyasal Bilgiler Fakültesi Dengisi (Cilt:XXVII, Sayı: 3, Eylül 1972):561-573.

KÖYLO, Kâzım; Ziraat Iktisadı, Zirai Işletmecilik, Cilt: l (Ankara: Ankara Universitesi Zira at Fakültesi Yayınları, Iklnci Baski).

KUTAL, Metin (1969), Teorik Esaslan ve Tabikat Bakımindan Asgari Ocret (Istanbul: Istanbul ÜniversitesI iktisat Fakültesi Yayını).

MAKAL, Ahmet (1997). Osmanlt Imparatorluğu'nda Çalışma llişkileri: 1850-1920 (Ankara: Imge Kitabevı Yayınları).

MAKAL. Ahmet (1999), Türkiye'de Tek Partili Dönemde Çalsşma llişkileri: 1920.1946 (Ankara: Imge Kitabevi Yayınlani).

MAKAL. Ahmet (2001), "Türkiye'de 1950-1965 Döneminde Ōcretli Kadın Emeğine liş̧kin Gelişmeler." Ankara Oniversilesi Siyasal Bilgiler Faküllesi Dergisi, (Cilt: 56, Sayı: 2, Nisan-Mayı-Haziran 20001): 117-155.

NALBANDOĞLu, Reşat (1948), "Türkiye'de Ziraat Iş̧̧ilerinin Durumu." ţ̧limai Siyaset Konferanslan, Birinci Kitap (Istanbul): 16-31.

SAYMEN, Ferit Hakkı (1954), Türk Iş Hukuku (lstanbul: Ismail Akgün Matbaası).

SUNAR, Kernal Sahir (1955), Türk Sendikalar Hukuku, Birinci Kitap (Ankara).

SOLKER. Kemal (1955), Türkiye'de Sendikacilik (Istanbul).

SENYAPIU, Tansı (1985), Ankara Kenlinde Gecekondu Gelişimi (Ankara: Batkent Konut Uretim Yapı Kooperatifleri Birligi Yayını).

TALAS, Cahit (1960), Türkiye Cumhuriyetinde Sosyal Politika Meseleleri (1920-1960) (Ankara: Ankara Öniversitesı Siyasal Bilgiler Fakültesi Maliye Enstitüsü Yayını).

TALAS, Cahit / DILIK. Sait / IŞIKLI, Alpaslan (1965), Türkiye'de Sendikaculik Hareketi ve Toplu Sözleșme (lktisadĩ Yönleri lle) (Ankara: Siyasal Bilgiler Fakültesi Maliye Enstitüsü Yayını).

TARUS, than (1946), "Cukurova'da Iş ve Iş̧̧i Bulma Rejimi," Çalş̧ma Dergisi (Yıl:1, Sayı:6, Mayıs 1946): 53-55.

TEKELl, Ilhan (1982a), "Kalkınma Sürecinde Marjinal Kesim ve Türkiye Özerinde Bir Deneme," Türkiye'de Kenlleșme Yazılan (Ankara: Turhan Kitabevi): 147-181.

TEKELl. Ihan (1982b). "Türkiye'de Tarımda Mekanizasyonun Yarattığı Yapısal Dönüşümler ve Kırdan Kopus Süreci," Türkiye'de Kentleșme Yazılan (Ankara: Turhan Kitabevi): 65-119.

TEKEll, Ilhan / ILKIN, Selim (1988), "Devletçillk Dönemi Tarım Politikalars," Şevket Pamuk, Zafer Toprak (Derleyenler), Türkiye'de Tarmsal Yapllar (Ankara: Yurt Yayınları): 37-90.

TOMMERTEKIN, Erol (1967), Istanbul'da Bir Sanayi Bölgesi: Bomonti (Istanbul: Istanbul Üniversitesi Coğrafya Enstitūsü Yayını). 
TUMERTEKIN, Erol (1968), Tũrkiye'de ķ Gợ̆ler (Istanbul: Istanbul Universitesi Coğrafya Enstitüsũ Yayını).

TURKAY, Orhan (1968), Gizli Isssizlik (Ankara: Ankara Universitesı Siyasal Bilgiler Fakültesi Yayın).

TURKIYE VE ORTA DOđU AMME IDARESI ENSTITÚSŌ (TODAIE) (1958), Sehinerin Gelismesi ve Sosyal Programlar - Adana ve Karabük Şehirleri Hakkunda Bir Araşturma (Coğaltma), (Ankara).

ANKARA UNIVERSTTESI SIYASAL BILGILER FAKOLLTESI (SBF) (1954), Türkiye'de Ziraí Makinalaşma • Ziraalta Makina Kullanulmasıın Doğurduğu Teknik, Ekonomik ve Sosyal Meseleler Ozerinde Bir Araştıma (Ankara: Ankara Ünjversitesı Slyasal Bilgiler Fakültesi Yayını).

URAN, Hilmi (1939), Adana Ziraat Amelesi (Istanbul: Vakit Matbaası).

VARLER, Oktay (1978). Türkiye Tanminda Yapısal Değişme, Teknoloji ve Toprak Bolüşümü (Ankara: Devlet Planlama Teşkilatı Yayını).

YASA, Ibrahim (1966). Ankara'da Gecekondu Alleleri (Ankara: Sağlık ve Sosyal Yardım Bakanlığı Sosyal Hizmetler Genel Müdürlügü Yayınları).

YAVUZ, Fehmi / KELEȘ, Ruşen / GERAY, Cevat (1978), Sehircilik, Sorunlar Uygulama ve Politika (Ankara: Ankara Üniversitesi Siyasal Bilgiler Fakültesi Yayını, Ikinci Bası).

\section{Kurum Yayınları}

BAŞBAKANLK ISTATISTIK GENEL MÜDÜRLÖĞŨ (BlGM) (1948), Köyler Istatistigi - 1945 Anket Sonuçlan (Ankara).

BAŞVEKÂLET ISTATISTIK UMUM MÖDÜRLOĞU (BIUM) (1953), 1950 Ziraat Sayımu, 1- Köylü Nüfusun Hususiyetleri ve Zirai Bünyesi (Ankara).

BluM (1956), 1950 Ziraat Sayımu Neticeleri (Ankara).

BAŞVEKÂLET UMUMI MURAKABE HEYETI (BUMH) (1955), Iş ve Iş̧̧i Bulma Kurumu 1954 Yll Raporu (Ankara).

CALSSMA DERGISI (CD) (1947), Yil:2, Sayı:24, Kasım - Aralık 1947.

ÇAUŞMA VEKÂLETI DERGISI (ÇVD) (1953), Cild:1, Sayı:1, Mart, Nisan, Mayıs 1953.

DEVLET ISTATISTIK ENSTITÜSÖ (DIE) (1965a), 1963 Genel Tanm Sayımı Ornekleme Sonuçlan (Ankara).

DIE (1965b), Istatistik Yıllığı 19641965 (Ankara).

DIE (1969), 1965 Genel Nüfus Sayımı Sonuçlan, Nüfusun Sosyal ve Ekonomik Nitelikleri (Ankara).

DIE (1973), Türkiye'de Toplumsal ve Ekonomik Gelişmenin 50 Yilh (Ankara).

DIE (1977), Türkiye Istatistik Yılliğı 1977 (Ankara).

DEVLET PLANLAMA TEŞKILATI (DPT) (1963), Kalkıruna Planı, Birinci Beș Yul: 1963-1967 (Ankara).

DPT (1967), Kalkırnma Planı, Ikinci Beş Yıl: 1968-1972 (Ankara).

IŞ VE IŞÇ BULMA KURUMU GENEL MÜDÜRLÖĞÜ (IIBK) (1957), Doğu Karadeniz Bölgesinde Çalışma Imkanlannin Artınlmast Noklai Mazanndan \ş Gücünün Kiymetlendirilmesine Ait Tetkikler (Cogaltma) (Ankara).

IIBK (1959). Akdeniz Bölgesi lş Gücü Anketi Raporu (Çoğaltma) (Ankara).

IIBK (1962), Ege Bölgesi Isgücü Anketi Raporu (Çoğaltma) (Ankara).

SAĞLK VE SOSYAL YARDIM BAKANLIĞl (SSYB) (1970), Türkiye Nüfus Araştımalanndan Elde Edilen Hayati Istatistikler, 1966-1967 (Ankara).

TARIM BAKANUČl (1968), Türkiye Tarminda Gelişme Ëgilimi, Grafik ve Istatistikler. 1938-1966 (Ankara). 